Portland State University

PDXScholar

\title{
Radicalism in American Political Thought : Black Power, the Black Panthers, and the American Creed
}

Christopher Thomas Cooney

Portland State University

Follow this and additional works at: https://pdxscholar.library.pdx.edu/open_access_etds

Part of the African American Studies Commons, Political Science Commons, Race and Ethnicity Commons, and the United States History Commons

Let us know how access to this document benefits you.

\section{Recommended Citation}

Cooney, Christopher Thomas, "Radicalism in American Political Thought : Black Power, the Black Panthers, and the American Creed" (2007). Dissertations and Theses. Paper 3238.

https://doi.org/10.15760/etd.3228

This Thesis is brought to you for free and open access. It has been accepted for inclusion in Dissertations and Theses by an authorized administrator of PDXScholar. Please contact us if we can make this document more accessible: pdxscholar@pdx.edu. 


\section{THESIS APPROVAL}

The abstract and thesis of Christopher Thomas Cooney for the Master of Science in Political Science were presented July 31, 2007, and accepted by the thesis committee and the department.

COMMITTEE APPROVALS:

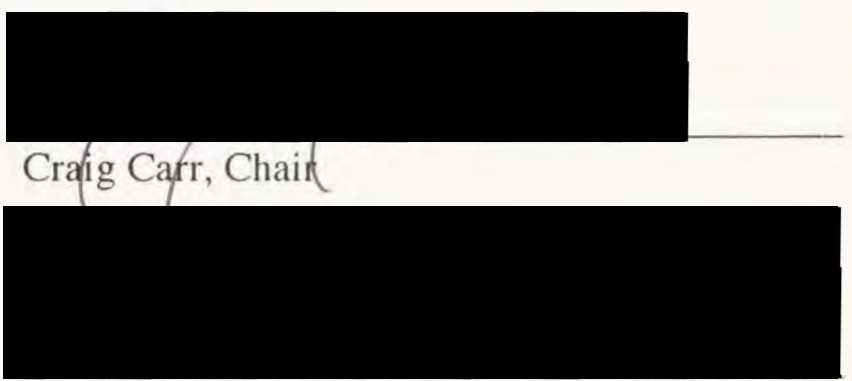

David Kinsella

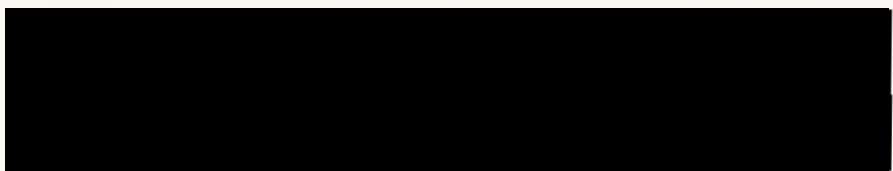

Darrell Millner

Representative of the Office of Graduate Studies

DEPARTMENT APPROVAL:

Ronald L. Tammen, Director Hatfield School of Government 


\section{ABSTRACT}

An abstract of the thesis of Christopher Thomas Cooney for the Master of Science in Political Science presented July 31, 2007.

Title: Radicalism in American Political Thought: Black Power, the Black Panthers, and the American Creed.

American Political Thought has presented somewhat of a challenge to many because of the conflict between the ideals found within the "American Creed" and the reality of America's treatment of ethnic and social minorities. The various forms of marginalization and oppression facing women, blacks, Native Americans, and AsianAmericans have been as much a part of the story of America as have been natural rights and the Constitution.

Taking this into account, this thesis is an effort to argue that the radicalism on display in the Black Panther Party, a group that emerged in the turmoil of the 1960's, was a direct descendent of the ideas found within the Black Power movement. It will be argued that these militant critiques of American society were radical, but were not so radical as to be viewed as outside of the context provided by the ideals found in the American Creed.

In order to do so, it will be necessary first to present and analyze the various approaches toward explaining the content and nature of the American Creed. The 
Creed will be presented as separate from American political reality, as an ideal type. As a result it appears to be a rather amorphous tool which can be used both by supporters of a more robust realization of the Creed's ideals and those who wish to limit the scope of these ideals.

Having discussed these approaches toward the American Creed, a discussion of radical political ideas will serve to introduce the Black Power movement and the later Black Panther Party. It will be argued that the radical ideas on display were born out of a frustration with American society, but were at the same time an endorsement of the American Creed. It will be concluded that the American Creed is a powerful force acting upon American political thought, so powerful that even those who should rationally reject the Creed forcefully embrace it. 


\title{
RADICALISM IN AMERICAN POLITICAL THOUGHT:
}

BLACK POWER, THE BLACK PANTHERS, AND THE AMERICAN CREED

$$
\text { by }
$$

\section{CHRISTOPHER THOMAS COONEY}

\author{
A thesis submitted in partial fulfillment of the \\ requirements for the degree of

\section{MASTER OF SCIENCE in POLITICAL SCIENCE}

Portland State University 2007 


\section{TABLE OF CONTENTS}

AMERICAN EXCEPTIONALISM AND THE CREED

2. RADICAL POLITICAL IDEAS 26

What are Radical Political Ideas?

3. ASCRIPTIVE AMERICANISM AND THE MESSAGE OF BLACK POWER 42

ASCRIPTIVE Americanism AND the Urban AFriCan-AMERican Population

The Emergence of the Black Panther Party 


\section{Preface}

To begin, it should be stated that the focus of this thesis is upon the radical left, those groups and individuals who are frustrated with the oppression and marginalization facing society's less fortunate members. Whether they are focusing on the poor, on ethnic or religious minorities, or upon those whose lifestyle choices are taken as abnormal, those on the radical left are interested in bringing positive change to society. There are of course, a number of organizations and individuals on the other side, the radical right. These are such groups as the KKK, who seek to limit freedom, silence dissent, terrorize innocent people, and erect systems of oppression to protect illconceived interests. One could conduct a similar analysis of the ideas on the radical right in American politics and their relation to the American Creed, and its conclusions could prove quite interesting. This thesis, however, is an effort that comes out of my interest in the 1960's as a period in American history when positive steps were taken that have made the country a much more fitting representative of the liberal ideas that have shaped American political thought. Because of this, the focus is upon the radical black voices that emerged to demand a more robust realization of the American Creed, and not upon those voices that sought to stamp out these efforts. 


\section{Introduction}

American political thought has presented somewhat of a challenge to many thinkers, for, in the country seen by most as the birthplace of modern democracy and liberal values there have been some incredibly severe limitations placed on large segments of the population. Although the country's political culture and thought has undergone enormous shifts since its founding, shifts that have broadened the scope of liberty and made equality a realizable concept for many, the legacy of slavery and the treatment of Native Americans have proven to be insurmountable hurdles to a more robust realization of the liberal ideal, For, although both slavery and the genocide of America's indigenous populations have long since ended, an indelible mark has been left, and the repercussions are ever present.

It will be argued here that, specifically with regards to African-Americans, the legacy of America's racism has given birth to radical political ideas. These ideas are born out of frustration with a society in which liberty and equality are preached from on high while people are denied both, based solely upon their race. What is interesting, and this is the central idea here, is that although these radical organizations certainly should be regarded as such, their radicalism does not exist in a vacuum. In fact, their radicalism is uniquely American, it is not a revolutionary standpoint, as 
much as it is a call to action based upon principles that have been thought of as the foundation of American society.

The methodology used to conduct this thesis is a literature survey and analysis. The popular thought regarding American political thought will be relied upon to provide the proper background from which to proceed. Following this, the speeches and writings of the various players in the Black Power movement, the movement for Civil Rights, and the Black Panther Party will be analyzed, and second hand scholarly accounts will also come into the discussion where needed.

In order to present this argument, it will be necessary first to briefly outline the popular ideas that have been put forth regarding the nature and content of American political thought, with a specific focus on the American exceptionalist tradition, that views America as being unique amongst Western societies. Within this tradition has emerged the idea that there is an "American Creed," one which is bound up within the tradition of liberalism but has also been shaped by the unique American experience. ${ }^{1}$ The idea of the Creed and its relevance to American social and political reality will be of central concern, but will be juxtaposed by the argument presented by Rogers Smith that although there certainly is evidence of an American Creed, there is also a good deal of evidence of extreme derivations from the Creed, which comes in the form of "ascriptive Americanism." It will be argued that Smith's account does weaken the case for America being a fundamentally liberal culture, but that this does not

\footnotetext{
${ }^{1}$ Huntington, Samuel P. American Politics: The Promise of Disharmony. Cambridge: Harvard, 1981.

${ }^{2}$ Smith. Rogers. Civic Ideals. New Haven; Yale, 1997.
} 
necessarily discount the power of the American Creed within American political thought. Rather, it will be shown that the Creed is in fact the determining factor of how Americans view their social and political worlds, but that the Creed is in a sense up for grabs, waiting to be utilized for any group that seeks to promote social and political change.

Having introduced these ideas, it will then be necessary to further discuss the idea of radical political ideas, to provide a more complete definition, and to show how the idea of radicalism relates to the notion of the American Creed and its power. Having done so, it will be necessary to discuss the sources of the radicalism on display in the Black Power movement, with specific attention being given to its relation to the national liberation movements that were occurring across the globe following World War II.

Having developed an understanding of radicalism that suits the purposes here, it will be necessary to examine the rise of assertive black voices, associated with the Black Power movement. In doing so, the later position taken by Malcolm X will be relied upon to provide an insight into the logic of Black Power. It is necessary to understand that the Black Power movement represented the frustrations of people that realized the relative futility of the Civil Rights movement because they understood firsthand the problems that ascriptive Americanism posed to any true realization of liberty and equality for African-Americans.

The work of Malcolm X and Stokely Carmichael will serve as an excellent introduction to the discussion of the Black Panther Party. The Black Panthers will be 
regarded as a paradoxical group that arose in the tumultuous late 1960's, and served to both further the cause of Black Power, and detract from the legitimacy that Black Power groups had sought to build. In doing so, the ideological positions of the various Black Panther leaders will be analyzed, to determine whether their radicalism represented a severe split from the ideas of the American Creed, or if they were much more closely related to American political thought than they would have liked to admit, which would give support to the argument that the Creed shapes the political thought of Americans.

Throughout this discussion, the focus will be upon the relation of the radical political ideas found in the Black Power movement to the idea of the American Creed. The central question will be how relevant the Creed has been to political reality, and how different social groups have sought to interpret the Creed. These varying interpretations will become the basis for arguing that although radical, the Black Power movement was in fact a natural progression in American political thought. This is not to argue that the message of the Black Power movement, and the Black Panthers in particular, was not adamantly critical of American society and politics. Rather, this radical stance was at times an incredibly rational expression of anger regarding the disconnect created between the competing traditions of the American Creed and ascriptive Americanism. The fact that the end-goals of the Black Power movement were a more complete liberty for African-Americans, including equality of opportunity and the fair enforcement of laws in the black community should serve as evidence for the argument presented here, that the amorphous nature of the American 
Creed has allowed it to be used as both a tool to restrict liberty, as in the case of ascriptive Americanism, as well as a means of shifting the dominant ideas within American political thought toward a more total realization of the liberal values that the American Creed represents. 


\section{American Political Thought}

In order to address the central topic of this discussion, the context of radicalism within American political thought, it is necessary first to understand what we know about the origins and content of the more mainstream elements of American political thought. In doing so, we will see that for many thinkers American political thought, as well as American political institutions, have been closely tied to the liberal enlightenment ideals of liberty, equality, and democracy. For many, these ideals are the bedrock of American political thought, but there have also been a number of skeptics who point to the historical treatment of minorities, specifically blacks, Native Americans, women, various European immigrants, wand Asians as evidence that these liberal ideals have been contradicted at best, and used as tools of oppression at worst. In any event, the works of a range of scholars will be presented here in order to provide a good background from which we can better understand radical politics within America.

\section{American Exceptionalism and the Creed}

The commonly held notion of American political thought is that it is dominated by what is referred to as American exceptionalism, the belief that the birth of America represented a shift in course of human relations that would come to change the world. Thoughts such as these date back to the earliest days of the American republic, during which time the framers of the constitution set out to create a system that would do 
away with the injustices of the European states. ${ }^{1}$ Within this context, this new republic would be one based on the enlightenment ideas of individual liberty and the fundamental equality of all citizens, although citizenship was limited by way of republican arguments that sought to limit participation in government to propertied white males. Some have argued that republican ideas of civic virtue also have played a large part in the development of American political culture, although many of these ideas have been rather hard to separate from the ideas bound up within liberalism, and some have questioned the depth of the republican thought with which the founders created the American republic. ${ }^{2}$ In either case, it is safe to say that there certainly were elements of republican ideas of civic virtue alongside the liberal values of liberty and equality, but that it was the liberal ideas that became the most trenchant.

Perhaps the vision of American exceptionalism is best represented in the work of Alexis de Tocqueville, who in 1831 traveled to America to conduct a study that has become the foundation for studies of American exceptionalism, as well as a useful interpretation of the coming age of democracy. What Tocqueville, himself a French aristocrat, found upon his journey through America was that there had emerged within this new republic a number of practices and beliefs that had created a society entirely unlike those found in Europe at his time. The characteristics which he found so unique were a shared sense of community amongst American citizens, reinforced by a

\footnotetext{
${ }^{1}$ Bailyn, Bernard. The Ideological Origins of the American Revolution. Cambridge: Harvard, 1992.

${ }^{2}$ Wood, Gordon. S. The Creation of the American Republic: 1776-1787. Chapel Hill, NC: University of North Carolina, 1998, 606-609.
} 
set of beliefs that were extremely egalitarian, perhaps even to a fault. ${ }^{3}$ Taken with the abolishment of any formal aristocracy through strict laws of inheritance, Tocqueville claimed that America had become the model upon which future democracies would be based.

His observations about the difference between the European class system and the lack of any formal system in America have become part of the foundation of American exceptionalist thought, in part because it brings to light the very sharp contrast between the European states and the society that developed in the New World. ${ }^{4}$ That is, the lack of the type of entrenched class, ethnic, nationalist, and religious tensions certainly should be seen as a crucial difference between the early American society and its European forbearers and one that would without a doubt alter the political thought and social relations of Americans for years to come. This absence of a formal aristocracy gave birth to the strong egalitarian spirit that Tocqueville argued dominated American political thought.

Tocqueville also emphasized the spirit of community that was present throughout much of America at the time of his visit. These feelings of community were in his mind a result of the egalitarian tendencies that ran so deeply throughout the society. ${ }^{5}$ This element of Tocqueville's account has become a popular area of study within the subject of American political thought, as scholars have developed these

\footnotetext{
${ }^{3}$ Tocqueville, Alexis. Tocqueville, Alexis. Democracy in America. New York: Penguin Classics, 2003, 228-231.

${ }^{4}$ Ibid, 207-209.

${ }^{5}$ Ibid, 583-587.
} 
ideas to support the notion that Americans are for the most part, tolerant and respectful people, ${ }^{6}$

Tocqueville's account was not without its criticisms though, of which the most troubling for Tocqueville was the fear he had that American democracy would breed conditions that would serve to stamp out any dissent, a concept which he referred to as the tyranny of the majority. ${ }^{7}$ By this, Tocqueville was indicating that perhaps the conditions which made America so unique amongst the nations of his era would also lead to an overall decline in the quality and beauty of philosophy, art, and other forms of expression and would instead usher in a rather mediocre society, in part because there was a tendency to view deviations from the norm, whether these were brilliant or tawdry, as bad or untrustworthy.

There is another element of Tocqueville's account of America which is quite relevant to the argument presented here. This can be found in his description of the great differences between the North and South, differences so great that he refers to there being three races within America, these being Northerners, Southerners, and African-Americans. ${ }^{8}$ He observed that many Southerners were much more like the aristocrats of Europe, in their aversion to labor of any kind and their love of extravagance. His outlook on the possibility of any kind of integration in the South is cloudy, to put it mildly, because he did not believe that these lazy aristocrats would ever be able to view their black neighbors as equals, and they had become so

\footnotetext{
${ }^{6}$ See: Wolfe, Alan. One Nation After All. New York: Penguin, 1998. Also Levy, Bernard-Henri. American Vertigo. New York: Random House, 2006.

${ }^{7}$ Tocqueville, 292-296.

${ }^{8} \mathrm{Ibid}, 371-478$.
} 
accustomed to using slave labor that they would forever view work as distasteful, fit only for blacks or poor whites. He goes on to suggest that perhaps the only solution would be for blacks to leave the South, and perhaps the country entirely.

Although his predictions proved to be a bit dire, there is a good deal of insight to be gained from including Tocqueville's description of the racial divides in the South in a discussion of the Civil Rights movement of the 1960's, because it was during this period that the racist and backward nature of the political leaders of the South became fully apparent to all Americans. This became one of the most successful strategies for the leaders of the movement, to expose men such as George Wallace or "Bull" Connor to the broader American public, and by way of Soviet propaganda, the world. ${ }^{9}$ By staying committed to non-violent tactics, even when faced with fire hoses and attack dogs, the black leaders and participants in the Civil Rights movement exposed the brutality of these white leaders and their philosophy of hate. Whether the reaction came out of a sense of sympathy for Southern blacks or out of a sense of necessity due to the pressures of the Cold War, it clearly led to a demand for Jim Crow laws to be ended.

Continuing the tradition of foreign eyes providing an exploration of American political culture, Gunar Myrdal, a Swedish sociologist and economist, conducted a study of the condition of blacks in America. ${ }^{10}$ He wrote from the Tocquevillian

\footnotetext{
${ }^{9}$ Klinker, Philip A. and Rogers M. Smith. The Unsteady March; The Rise and Decline of Racial Equality in America. Chicago: University of Chicago, 2002, 249251.

${ }^{10}$ Myrdal, Gunnar. An American Dilemma: The Negro Problem in a White Nation. New York: McGraw-Hill, 1964.
} 
perspective, that America was a uniquely liberal culture that was free from the ethnic, nationalist, and religious tensions found in Europe, and was committed to liberal egalitarian values. Extending upon Tocqueville's analysis, he argued that America had developed a set of values that he labeled the "American Creed." The Creed was composed of the often competing ideals of liberty and equality, a battle that Myrdal felt had been raging since the founding of the country, with equality seeming to hold the lead in the age of the New Deal. ${ }^{12}$

Myrdal was attempting to understand and describe how, in the liberal culture described by Tocqueville, African-Americans had been marginalized and oppressed to such a great degree. In doing so, he conducted a broad survey of the socio-economic conditions facing blacks in America. His conclusion was that the injustice had been allowed to continue because it had been justified through use of the Creed, specifically the focus upon liberty. It was because Southern and Northern racists had been able to argue for their ability to segregate and discriminate based upon their own personal liberty that a "vicious circle" had arisen that trapped black Americans in poverty. ${ }^{13}$ In Myrdal's view then, it was the competing nature of the values of the Creed that had led to the oppression and marginalization of African-Americans.

Written in the tradition of Tocqueville, American scholar Louis Hartz wrote what has become the starting point for modern discussions of liberal American political thought. The Liberal Tradition in America presents Hartz's argument that

\footnotetext{
${ }^{11}$ Myrdal, 3.

${ }^{12}$ Ibid, 8-9.

${ }^{13}$ Ibid, 207.
} 
American political thought was composed of the core elements of liberalism, and that this liberalism shaped American attitudes to such an extent that even those who claimed to be radicals or socialists were influenced to such a degree by liberalism that their political objectives and messages were overwhelmingly liberal in character. In this regard he described the American socialists' relation to European socialists as being similar to the relation between a "postage stamp and a life-size portrait: all the lines are there, all the features, but the size is very small."14

He put a good deal of his effort toward showing how important the idea of the "Lockean race" to accumulate wealth and produce new things had been to the development of modern American political ideas. ${ }^{15}$ In this regard, he continued with Tocqueville's conception of American exceptionalism, he argued that even when the actors in question sought to place themselves outside of the mainstream of American political thought, they could not escape their "American-ness," and would, for example, not be able to truly identify with socialist movements as they existed in Europe, simply because they could not adopt the European mindset and all that came with it And it was also because of this relationship Americans have with liberal ideals that the monopolists of late 1800's sought to portray their rise to power as being wholly the product of their own hard work and use of natural resources, an example that any good American could follow if she would only work hard. ${ }^{16}$

\footnotetext{
${ }^{14}$ Hartz, Louis. The Liberal Tradition in America. San Diego: Harvest, 1991, 244. ${ }^{15}$ Ibid, 219.

${ }^{16}$ Ibid, 213.
} 
Another important influence upon American exceptionalist thought was the presence of the frontier for much of the early life of the republic. ${ }^{17}$ The lands west of the Mississippi had, for over 200 years provided a certain complement to the Lockean liberal notions of the power of labor and the natural freedom of men; these lands were seen by many as virtually empty with the only inhabitants being what were regarded as primitive or savage tribes that were not utilizing the full potential of the land upon which they lived, and therefore could not claim ownership to these areas that had been their home for years. It is interesting here to view the inherent contradiction in this mode of thinking; that is, even while adhering to notions of natural human value and property rights, the majority of early Americans had little qualms about destroying the Native American cultures that had been living upon these lands for centuries. This is one of the many chinks in the armor of the notion that America has been a liberal nation, committed to Lockean freedom, it shows that when push came to shove liberal values were often given a backseat to economic or territorial imperatives, that were backed up by pseudo-scientific claims regarding the sub-human status of non-whites, an issue that will be addressed in more detail shortly.

The West also provided the very useful function of being a sort of safe haven for minority religious or ethnic groups that faced persecution in the more populated Northeastern seaboard. Aside from this function, the West also represented an opportunity for Americans to begin new lives for themselves and their families, a way

${ }^{17}$ This sentiment is expressed well in Turner, Fredrick Jackson. The Frontier in American History. New York: Dover, 1996. 
to escape creditors, employers, wives, husbands, and anything else that was seen as obstructing the individual's pursuit of happiness. Adding to this sense of freedom was the creation of numerous state universities that took it upon themselves to offer higher education to a broader segment of society, and often provided concrete functional educations that would produce better agriculturalists and engineers. ${ }^{18}$ Of course, the frontier soon became little more than a myth as waves of settlers moved in, converted the once wild lands into productive zones and began forming communities. Although the spirit of individualism and liberty is certainly still a very important sentiment in the West, the idea of total freedom that the frontier embodied has disappeared, much like the native tribes and bison that used to roam these lands.

The removal of the escape to the frontier from the American conscious has certainly had an impact upon the development of American political thought. It could be argued that this phenomenon might have left many tensions unsolved. That is, the option of escaping to the West likely served to delay many of the tensions between ethnic groups that boiled over in later years, and the increased isolation may actually have led to increased conflict when the frontier dried up and differing groups were forced to deal with one another. Also, Gunnar Myrdal argued that the waning of the frontier had led to a decline in the idea of the "rugged individual" in America, and that this in turn had led to a greater emphasis placed upon equality of opportunity. ${ }^{19}$

In a more recent example of American exceptionalist thinking, Samuel Huntington has argued that the liberalism discussed by Hartz and Tocqueville, among

\footnotetext{
${ }^{18}$ Turner, 266-67.

${ }^{19}$ Mydal, 210.
} 
others, can be defined using Mydal's term, the American Creed. ${ }^{20}$ The Creed's core values are "liberty, equality, individualism, democracy, and the rule of law under a constitution," with each being connected to the others in a system of mutual reinforcement, in Huntington's view. ${ }^{21}$

Huntington is perhaps best known for his work on the coming "Clash of Civilizations," the idea that increased interconnectedness on the global level will lead to violent conflicts between the Western world and the Islamic world. ${ }^{22}$ It is fitting that Huntington pushes the idea of national identities out to the global level in his work within the field of international relations, because it is the national identity of America, the Creed, that is central to his discussion of American political thought.

...Ideas of constitutionalism, individualism, liberalism, democracy, and egalitarianism are no monopoly of Americans. In some societies, some people subscribe to many of these ideas and in other societies many people subscribe to some of these ideas. In no other society, however, are all of these ideas so widely adhered to by so many people as they are in the United States. People sometimes speak of an American "ideology." But in the American mind, these ideas do not take the form of a carefully articulated, systematic ideology in the sense in which this term is used to refer to European belief systems such as traditional conservatism, liberalism, Marxism, social democracy, and Christian democracy. They constitute a complex and amorphous amalgam of goals and values, rather than a scheme for establishing priorities among values and for elaborating ways to realize values. ${ }^{23}$

The Creed, in this view, is the bedrock of American political thought, and it is in fact, what defines Americans as such. Because America has not suffered through

${ }^{20}$ Huntington, Samuel P. American Politics: The Promise of Disharmony. Cambridge; Harvard, 1981. 13-17.

${ }^{21}$ Huntington, American Politics: The Promise of Disharmony, 14.

${ }^{22}$ Huntington, Samuel P. "The Clash of Civilizations." Foreign Affairs, Summer 1993, 22-49.

${ }^{23}$ Huntington, American Politics: The Promise of Disharmony, 15. 
the historical strife that plagued Europe, there are not the sort of ethnic, religious, and nationalist tensions that make up the content of many European national identities. In the absence of these types of concrete definitions of who one is, the only thing that lets Americans view themselves as a unique community is their adherence to the American Creed. As Huntington describes it, this adherence is not held out of some principled understanding or philosophical inquiry. It is, rather, of an ingrained variety, and the tenets of the Creed are in that sense taken as truths from which all problems will find their solutions.

Huntington furthers this discussion by explaining how, in a liberal democracy, so many were excluded from political and social goods for so long with his conception of the gap between ideals and institutions, or the "IvI" gap. ${ }^{24}$ It is because modern life has brought with it at least the perception of the need for state apparatuses in order to settle disputes and maintain security that there have emerged a myriad of institutions created to deal with such issues. The problem is that these institutions often have enacted policies that run against the central tenets of the Creed, which were either embraced by the population through a sort of cognitive dissonance, or were viewed with such a high degree of cynicism that it was thought nothing could be done to bring about a change in the status quo. ${ }^{25}$

However, Huntington also presents the idea that there have been certain historical periods in which this indifference was shed and change was demanded. These are what he calls "periods of Creedal passion," and were represented in the

\footnotetext{
${ }^{24}$ Huntington. American Politics: The Promise of Disharmony, 39-41. ${ }^{25}$ Ibid, 61-75.
} 
Independence movement, the Jacksonian era, the Progressive era, and most recently in the 1960's and 1970's, or the S\&S years. ${ }^{26}$ It was during these times that the liberal ethos embedded within the American Creed overcame the cognitive dissonance and cynicism that wracks the minds of Americans during the times leading up to these Creedal passion periods, and as a result the IvI gap is exposed and a solution is demanded.

\section{Ascriptive Americanism}

This is a very intriguing view of American history, one that helps to explain how and why such practices as slavery and anti-immigrant fury have coexisted with the liberal egalitarian principles found in the Creed. But, it does not adequately explain the pervasive and popular nature of these anti-Creedal sentiments that are held amongst the people, regardless of the role of institutions. For this, we should turn to Rogers Smith's Civic Ideals. ${ }^{27}$ Smith argues that rather than the traditional two sources of American political thought; liberalism and republicanism, there is a third tradition, which he labels "ascriptive Americanism." Ascriptive Americanism is meant to define the constant thread within American political thought composed of racist and sexist thought that has sought to elevate white men above all other Americans by denying the personhood of groups such as women, Asians, and people of African descent.

...They [minorities] have instead been "lower races," "savages" and "unadmissables," slaves and servants, aliens and denizens, "unnatural" criminals and second-class citizens, wives and mothers. These statuses have been generated by ideological and institutional traditions of political identity...In contradiction to liberal democratic dictates, they do not define

${ }^{26}$ Ibid, $85-91$.

${ }^{27}$ Smith, Rogers. Civic Ideals. New Haven: Yale, 1997. 
civic status by consent or by universal rights. Instead they provide elaborate, principled arguments for giving legal expression to people's ascribed place in various hereditary, inegalitarian cultural and biological orders, valorized as natural, divinely approved, and just. That is why a multiple traditions approach to American political culture is necessary. ${ }^{28}$

In this sense, ascriptive Americanism is viewed as a competing set of ideas, that are often as deeply rooted as the American Creed. This is a fundamental contradiction to the idea that Americans define their political thought through the Creed, because it argues that they have also used these theories of racial hierarchy to define such ideas.

In Smith's construction of the shape of American political thought, his focus is upon the development of formal citizenship laws throughout the history of the American republic, up to the 1920 's. What emerges from this study is a clear tendency for political elites to frame issues so as to make minority groups the enemy of the middle or working class, often out of a perceived political necessity, and sometimes as a reaction to demands coming from elements of the white population. ${ }^{29}$ Smith's conception directly challenges Huntington's in the sense that many of the periods of Creedal passion that Huntington defends can be viewed not as movements toward a form of liberal egalitarianism, but as periods in which the powers that be sought to gain political support by scape-goating minority groups.

Also, Smith presents the course of ascriptive Americanism as being closely tied to the moments during which strides were made to increase the scope of liberal democracy within America. In this sense, the periods of Creedal passion which Huntington is interested in have often been followed by a backlash from a good part of

${ }^{28}$ Ibid, 18.

${ }^{29}$ Smith, 35. 
the population, a notion that directly challenges the idea that deviations from the Creed have been the result of changes to the economic and social core of the country.

The most telling contrast between these two conceptions can be found in their treatment of the Jacksonian era. According to Huntington's argument, Jacksonianism represented a reaction to the emerging upper class that was based on a liberal populism that was firmly rooted in the ethos of the Creed. ${ }^{30}$ However, Smith argues that although this characterization has its merits, perhaps the more prominent element of Jacksonianism was its virulent anti-Native American stance. ${ }^{31}$ Jackson and his comrades used the specter of the Indian to build support amongst lower and middle class whites and seized upon this opportunity to carry out such actions as removing Native people from lands that were of great economic worth, as in the case of the Cherokee Indians in Georgia. ${ }^{32}$

As Smith details, one of the arguments that was most popular amongst political and economic elites throughout the 1800's and early 1900's was a type of racially based scientific argument that justified the unjust treatment of ethnic and social minorities. These arguments were based on scientific studies that claimed to prove that White Anglo Saxon Protestants (WASPs) were in many ways, superior to all other groups of humans. Whether based on studies of the cranium size of various ethnic groups, or upon faulty sociological examinations of life in immigrant or black communities the conclusions were the same, that WASPs were superior, and should

\footnotetext{
${ }^{30}$ Huntington. American Politics: The Promise of Disharmony. 223.

${ }^{31}$ Smith, 197-242.

32 Ibid, 235.
} 
therefore maintain their hold on power. Smith shows that even amongst the celebrated Progressives of the early 1900's these sentiments were evident. ${ }^{33}$

With hindsight, these types of arguments have for the most part fallen by the wayside, and for good reason. As modern science has shown, there is no validity to claims of racial superiority, and the idea that taking the illiteracy rates and poverty rates amongst immigrant and other minority communities to prove their inferiority falls apart when you take into account the fact that many of these people were denied access to anything approaching equal educational opportunities. It is preposterous to claim that a group of people, blacks for example, who had been punished for learning to read and write are somehow unable to read and write because of some inherent inferiority.

However preposterous, it can be countered that although much of the credibility of the research methodology has been shaken for these types of hierarchical theories of mankind, these ideas have not altogether disappeared. As Smith and others note, as recently as the 1980 s it was a popular belief that there were some genetic distinctions between whites and other races that made whites more intelligent, and just so happened to indicate that Latinos and blacks were better suited to physical activities. $^{34}$

Smith's account does not deny that liberalism has been an important influence upon American political thought; rather he argues that it was at times overshadowed by republican arguments that were often themselves used as fronts for first, WASP

\footnotetext{
${ }^{33}$ Ibid, 410-469.
}

${ }^{34}$ See Smith's discussion of the "Bell Curve" and related arguments: Smith, 488. 
supremacy arguments, and later more general white supremacist arguments. He provides a view of the development of American political thought that is not the story of progression that Huntington and others present. Within Huntington's writings and also within the popular understanding of American history, there is a certain notion that America has been steadily moving down the path towards a more allencompassing liberalism that should be seen as an ideal type.

In this view, American history has been on an upward path, first rejecting the tyranny of the European monarchy, then ending the tyranny of wealthy landholders, followed by the abolishment of slavery, and more recently ending the injustice of segregation in the South. Smith's presentation of American history is much more nuanced, it does not deny that there have been great strides made toward meeting the ideals bound up within liberalism, but it is much more honest about the fact that there have also been points when rather than moving toward this ideal, Americans have resisted change, and have gone in the opposite direction of a more total freedom for all citizens, and that often the arguments used by these regressive elements of American society have been wrapped up within the ideals found in the American Creed. In this regard, the power of liberalism is not disputed; in fact it is reinforced. The problem of course is that there is a fundamental contradiction on display when liberal ideals are used to deny persons access to these very ideals. The fact that many of the worst periods of ascriptive Americanism seem to emerge following strides toward bringing a more equal distribution of political, social, and economic resources to the population only serves to further the depth of this contradiction. 
Nothing represents this better than Smith's description of the events

following the Civil War. The initial positive steps taken during the Reconstruction era, were soon followed by a backsliding that allowed the Supreme Court to issue the famous "separate but equal ruling" in the case of Plessey V. Ferguson in 1896 that permitted segregation through a creatively racist interpretation of the US

Constitution. ${ }^{35}$ It is because of instances like this that Smith is incredibly skeptical of the idea that America is a liberal country, deeply committed to freedom and equality.

It should be noted that Huntington has further developed his analysis of American political thought, partially as a reaction to the work of Smith. In his recent work on the subject he admits that ascriptive Americanism has in fact existed alongside the Creed. ${ }^{36}$ The problem with this is that these modifications to his conception of the power of liberalism are followed by a lengthy argument against the influx of Hispanic immigrants into America. Here, Huntington is putting on a fine display of ascriptive Americanism by relying upon numerous facts and figures to argue that these Hispanic immigrants are unwilling to assimilate into American society. According to his reading of the facts, Hispanics don't want to learn English and they are committed to sending their earnings back to their families outside America. He goes so far as to describe the influx of these people as akin to an invasion force coming to take over America. ${ }^{37}$

${ }^{35}$ Smith, 377.

${ }^{36}$ Huntington, Samuel P. Who Are We? . New York: Simon \& Schuster, 2004, 49. ${ }^{37}$ Ibid, 256. 
How does this discussion of the popular conceptions of the content and origins of American political thought relate to the discussion at hand, which seeks to understand the presence of radicalism within American political thought? It is necessary because it will be argued that although the radicalism on display in the works of Malcolm X and the Black Panther Party was certainly adopted as a counter to popular American political thought, there was still present within these radical ideas and actions a certain liberal foundation, one that is indisputably American in character. That is, much like the "socialists in the wilderness" of the 1800's which Hartz describes, the black radical movement of the 1960 's could to a certain extent be described as being "revolutionaries in the metropolis."

Also, it was necessary to present the idea that there is an "American Creed," one that holds equality and liberty as the standards to which society should reach. Whether or not the Creed is actually realized is another thing entirely. As has been shown in the discussion of Smith, who controls the Creed is often the determinant of how fully and fairly the Creed's core principles will be distributed throughout society. If elites see an opportunity to gain power, or wealth, or support by use of the Creed, it often hasn't mattered whether the Creed was used in a contradictory manner or not. But, in the case of Cold War necessity it was elites that pushed for an expansion of liberal values to blacks, despite the fact that it alienated them from their Southern counterparts and in many cases their own ascriptivist ideologies.

Taking Smith's account into consideration, one can either take the evidence presented to indicate that perhaps the use of liberal ideals in American political 
thought has been a sort of hollow rhetorical tool used to whip up support for a particular program or policy, or take a less critical position, one that does not deny the problems of ascriptive Americanism, but also does not deny the power that the Creed has. That is, shouldn't the Creed be seen as an important determinant of American political thought even if it is often a rather nebulous, unrealized set of ideals? There may be some that reject outright the idea that liberal ideals can hold power even when they are used to restrict liberty and enforce inequality, and they certainly have a good case to make. But the ideas bound up in the Creed are powerful enough to have proven to be a sort of arsenal with which marginalized groups have been able to fight the injustices present within American society, proving their relevance and value within American political thought. The fact that ascriptive Americanism has existed alongside ideas of liberty and equality does weaken the argument that America is a fundamentally liberal culture, but this does not discount the power of the American Creed.

What then, should we conclude about the relationship between the American Creed and the illiberal treatment of minorities and women throughout the history of the American republic? My argument is that because the Creed is itself rather undefined in a concrete manner, the various usages of Creedal values have been rather amorphous. It supports the idea developed so far, that American political thought is defined by the Creed, because it shows that the Creed is up for grabs, so when a segment of the American population seeks to change the political landscape it is the Creed that they turn to in order to present their cause as an American one. This 
particular understanding of the Creed is central to this thesis, because the argument presented is that the Black Panther Party and their Black Power predecessors defined their movements within the broad boundaries of the Creed. The Creedal values with which they identified were the respect of the rule of law, individual liberty and responsibility, and equality of opportunity, which they felt had been denied to them based upon their skin color and economic standing. The fact that one of America's most marginalized and oppressed ethnic groups would still rely upon the Creed to support their movement serves to reinforce the idea that the American Creed is the most powerful force acting upon American political thought, even if the evidence shows that the reality of American society has seldom lived up to the ideals of the Creed because of the presence of ascriptive Americanism. 


\section{Radical Political Ideas}

In order to better understand the nature and content of the radicalism that the Black Power movement and the Black Panther Party presented it is necessary to both better define what exactly is meant by radical politics, and to understand how radical politics have been pursued within the broader landscape of American political thought. How should we understand the presence of groups such as the Black Panthers, who sought to empower the marginalized African-American population through a militant critique of the American political and social landscape? Were they offshoots of foreign national liberation movements, fueled by a Marxist-Leninist outlook, or were they a unique American political movement? The answer, it seems, is neither. The Black Panthers, and many of their sister organizations, were too detached from the foreign movements to be viewed in the same light, and too frustrated with the liberalism which had allowed Jim Crow laws in the South and racist legal and economic practices in the urban north to be associated with either. It will instead be argued that although they would likely be the last to admit it, the political vision of the Black Panther party was not so different from that of liberalism, not the liberalism of the Democratic party in 1960's America, but the liberalism that holds individuals as sacred possessors of rights who are capable of great things given the freedom and opportunity to pursue their sense of the good life. 


\section{What are Radical Political Ideas?}

Radical political ideas are a rather tricky concept to discuss for a number of reasons.

One such reason is that political ideas are seldom radical beyond their specific historical and social setting. For instance, at one time liberal thinkers such as John Locke were seen as radical in their rejection of the status of the monarchy, but in the years following their work these ideas have become "self-evident" to many. The same can be said for many new ideas that have arisen in the physical sciences or such disciplines as economics. One can think of Thomas Kuhn's work regarding shifts in scientific thought here, often times it was those thinkers who were dismissed as radical or unorthodox who provided the spark needed to push scientific understanding into a new world of possibilities and explanations. ${ }^{1}$ In this regard, we can understand that radicalism, in the realm of political thought, is often a description used to put the ideas under question into their proper historical and social context.

But what is this context? How do ideas that we define as radical differ from those ideas that are considered mainstream or status quo? There is very little in the way of useful formal definitions for such concepts, but this does not mean that these types of definitions are impossible. As the use here of a scientific thinker such as Kuhn shows, the necessary tools for defining radical political thought are out there, they need only to be applied to the discussion at hand.

\footnotetext{
${ }^{\mathrm{I}}$ Kuhn, Thomas S. The Structure of Scientific Revolutions $3^{\text {rd }}$ ed. Chicago: University of Chicago, 1996.
} 
On a basic level, there is a sort of intuitive definition of radicalism. One can read a statement or view some event and think; "wow, that's a radical idea." In this regard, radicalism describes ideas that range from new and exciting to shocking and revolting. There is also the issue of the "radical" label, which can be adopted by a group or person to outwardly display their level of divergence from the status quo. The radical label can also be applied to a group from outside sources, such as the state, as a means of identifying dangerous or fringe ideas. Of course, these two uses of the term are not mutually exclusive. As we will see the Black Panther Party both openly adopted the radical title, and at the same time were dismissively or cautiously regarded as radicals by many in the mainstream media and political sphere.

Along the same lines there is also a distinction to be made between radicals and activists, not all activists are radicals, and not all radicals are activists. It is when radical ideas are wedded with activist strategies that a more robust radical political stance is developed. As an example of the difference between activist and radical politics the Civil Rights movement provides an excellent case. Certainly many of the activist leaders and participants in the various events of the movement were radicals, Stokely Carmichael for one, but many were not. Their tactics may have been construed as radical by many, especially within the Southern white power structure, but there is certainly a distinction to be made between the message of the Civil Rights movement and the later Black Power movement in terms of the degree of radicalism. Voting rights and equal protection under the law were not radical ideas, as was 
discussed in the previous chapter these are the ideas that define Americans as such, so many of the activists involved were not necessarily radicals at all.

In order to provide a more substantive argument, we will need to work with a definition of radicalism that isn't based solely on labels, either adopted or prescribed. One such concept can be found in the work of Michel Foucault, the French philosopher who sought to conduct an "archaeology of knowledge" by delving into seemingly highly specific social phenomena, such as the nature of punishment within the Western world, or the institutions erected to diagnose and react to insanity. ${ }^{2}$ Although Foucault's subject matter was broad in its range we can take from it some very concrete concepts that will suit this project quite well.

Of these, none is as central as the idea of dominant discourse. In this context, the dominant discourse is meant to describe what could be called the status quo, but Foucault's conception is much deeper than that. For it does not just describe the mainstream thoughts and beliefs of a given society, the dominant discourse shapes these thoughts and beliefs. ${ }^{3}$ In this sense, the dominant discourse should be seen not as the status quo but as the driving force behind the content of the status quo. It dictates answers to such questions as who is a citizen, what types of behaviors constitute criminal activities, what sanity is, and so on. The dominant discourse in this regard is similar to the way that Huntington describes the American Creed, as being a sort of pre-conceived system for interpreting the world without any sort of deep

\footnotetext{
${ }^{2}$ Foucault, Michel. Colin Gordon ed. Power/Knowledge: Selected Interviews and Other Writings 1972-1977. New York: Pantheon, 1980.

${ }^{3}$ Ibid, 78-108.
} 
philosophical reasoning to back it up, but in Foucault's conception, the dominant discourse is presented as more of a tyranny over competing ideas and minority groups than the American Creed is, at least in Huntington's mind.

Perhaps it is necessary to point out that much of Foucault's work on the idea of dominant discourses should be seen as following the work of Antonio Gramsci, who introduced to the world the concepts of hegemony and superstructure. These terms were meant to present the idea that within society there exists a certain mindset that holds a monopoly on the truth, and thereby shapes the lives and thoughts of all those within said society. In his mind, capitalism had become a hegemonic idea, one that took precedence over all others and one that had become so ingrained within societal institutions and ideas that its truth had become self-evident and indisputable. ${ }^{4}$

\section{Radical Politics in Black America}

It fits nicely with our discussion so far to note that Foucault viewed the most interesting of society's members to be those minority groups that for whatever reason found themselves outside of, or otherwise at odds with, the dominant discourse. This is where the concepts discussed here can fit into our model of the relation of radical politics to the broader political landscape. As our focus here is upon the Black Power movement, and specifically the Black Panthers as a group representing America's marginalized urban black population, we can identify their position as being rather removed from the broader landscape of American political thought, or, the dominant discourse. However, this removal is not total, it will be argued that their place within

${ }^{4}$ Gramsci, Antonio. Selections from the Prison Notebooks. New York: International. 2005, 181-182. 
the historical tradition of American political thought influenced their radicalism to a great degree.

It should be noted that one of the more popular radical or leftist thinkers in recent American history is C. Wright Mills, who wrote the Power Elite in 1955. According to Mills, American society was controlled by a select group of elites from the military, political, and business worlds. ${ }^{5}$ Interestingly, one of the primary problems in Mills' view was that the members of these elite circles were unwilling to admit their status as elites. So, if one were to ask an elite if he was an elite, he would reply no, but would go back to eating lunch or playing golf with his friends and associates, who would all happen to be elites. ${ }^{6}$ Mills provides a good example of those elements within American society that, according to Rogers Smith have to a large part controlled the Creed.

Just as the student movements of the 1960's weren't the first American radical organizations, the Black Power movement did not represent the birth of radical political thought within the black population. The most widely known early black radical was Nat Turner, who led a slave revolt in 1830 . It should also be pointed out that following both World War I and II African-American protest movements sprang up demanding fair treatment for black men who had served in the military but returned home to marginalization and mistreatment. ${ }^{7}$ This notion that the movement for racial justice in America has been a process spanning decades and has been called by some

\footnotetext{
${ }^{5}$ Mills, C. Wright. The Power Elite. New York: Oxford, 2000, 1956. ${ }^{6}$ Ibid, 14.

${ }^{7}$ Klinker, Philip A. and Rogers M. Smith. The Unsteady March; The Rise and Decline of Racial Equality in America. Chicago: University of Chicago, 2002.
} 
the "Long Civil Rights Era," as a means of showing the depth and magnitude of the movement. $^{8}$

Of these earlier radical black movements, perhaps none were as prominent as that led by Marcus Garvey. Garvey was a separationist who sought to remove blacks from American society entirely, hoping to establish an African nation that would become the foundation for a new black society. His most widely known tactic was the creation of the Universal Negro Improvement Association which sought to build black owned businesses, the flagship of which was the Black Star Line, a fleet of sailing ships meant to take America's black population back to Africa. ${ }^{9}$ Garvey, who was a very outspoken critic and evidenced more than a few indications of prejudice was eventually pursued by a young J. Edgar Hoover to the point at which the Black Star Line was shut down due to charges of mail fraud and tax evasion. Garvey's radicalism was quite popular at the time, with a reported two million active supporters, a number that has been disputed, but it has been shown that at least 250,000 working members were a part of the UNIA in the 1920 's. ${ }^{10}$ Garvey was very influential in the lives of a young couple that would give birth to Malcolm Little, the man who would later adopt the title "Malcolm X" after having joined the ranks of the Nation of Islam,

${ }^{8}$ Self, Robert O. "The Black Panther Party and the Long Civil Rights Era." Found in: Lazerow, Jama and Yohuru Williams eds. In Search of the Black Panther Party: New Perspectives on a Revolutionary Movement. Durham, NC: Duke, 2006.

${ }^{9}$ Cronon, Edmund D. Black Moses: The Story of Marcus Garvey and the Universal Negro Improvement Association. Madison, WI: University of Wisconson, 1964, 5055 .

${ }^{10}$ Klinker and Smith, 118. 
a separatist group that drew much of its ideological foundation from the thought of Marcus Garvey. ${ }^{11}$

Just as Malcolm X and Marcus Garvey before them, the leaders of the Black Panther Party represented the frustrations of America's black population with regard to their role in society. As the discussion of Rogers Smith's notion of ascriptive Americanism illustrates, for the length of the American political system's life certain groups had been barred from political participation outright, or so socially marginalized that political participation was a fruitless enterprise. These groups included African-Americans, Native Americans, women, and Asian-Americans. ${ }^{12}$ This is an extremely important notion with regards to the question of radicalism within American politics because it provides us with the fundamental idea that will allow this discussion to proceed. This fundamental idea is that of America's radical groups, it is those that have arisen as a reaction to ascriptive Americanism that provide the most stark contrast to the idea that America is a fundamentally liberal culture. It is only those groups that have been segregated and marginalized from the broader society as a whole that will develop truly radical political ideas, because they have witnessed first hand both the benefits that liberty and equality have for whites, and the empty nature of such ideals and values when they are denied outright. In this regard though, it should be pointed out that not all of these marginalized groups have emerged with radical political ideas, specifically the Eastern European and Asian immigrants that Higham discusses. A possible explanation is that the deep cultural ties that were

\footnotetext{
${ }^{11}$ Haley, Alex. The Autobiography of Malcolm X. New York: Ballantine, 1992, 9. ${ }^{12}$ Smith, Rogers. Civic Ideals. New Haven: Yale, 1997.
} 
severed, in the case of blacks by slavery, and in the case of Native Americans by decimating their populations and taking their ancestral lands, allowed the European and Asian immigrants to find some sense of solidarity and community that allowed them to push for inclusion without resorting to radicalism.

In order to support this claim about the nature of radicalism on display in the Black Power and Black Panther movements, it is necessary to briefly examine the sources of radical black politics within America to determine whether or not this idea is worthwhile. In doing so, a central topic that will need to be addressed revolves around the role that foreign movements played in bringing about the types of radical organizations that the BPP represents. We will need to determine whether the ideologies of such leaders as Malcolm X, Marcus Garvey, and Huey Newton were as entwined with third-world liberation movements as they presented them to be. How much did these American leaders take from Mao, Fidel Castro, Che Guevera and other such foreign sources? This is a crucial question because if in fact it is concluded that the impetus for radicalism within America has been mainly foreign in origin, it takes away from the argument presented here, that radicalism in American political thought is a product of internal conditions.

The years following World War II proved to be quite tumultuous. As European powers began to give up on colonialism many of the nations making up the "third-world" became enmeshed in struggles to either gain their own independence, or having already done so, became torn with internal struggles over who would control these states. This was the era of the national liberation movement. From Cuba to 
Algiers revolutionaries swept away colonial or monarchical governments using the popular appeal of Marxism-Leninism to form new states, often communist in mindset.

It is clear that these events had an influence upon Americans, and particularly among African-Americans who were witnessing the birth of a plethora of new African nations that would ostensibly be free from the interference of the great imperial powers of the time, often seen as America and its European allies. ${ }^{13}$ With hindsight of course, one can look at these sentiments with great skepticism. For, it seems to be the case that in many of these countries, even after shaking free from "capitalist imperialism" the heavy handed Soviet state stepped in to replace its predecessors. ${ }^{14}$ While Marxism-Leninism certainly offered an alternative to capitalist rule, it was not the sort of alternative that would bring an end to foreign exploitation and dominance.

In any event, blacks within America took notice of the great shifts in the international landscape, and soon a good number would come to consider themselves as comrades in arms with the many national-liberation movements coursing through the third-world. The question is, did these African-Americans find their inspiration from these movements and define their political aims and philosophy accordingly, or did these movements act as more of a catalyst for prior held ideas of how to change American society so as to eliminate the kind of marginalization and oppression that had been brought about by ascriptive Americanism?

${ }^{13}$ Singh, Nikhil Pal. Black is a Country: Race and the Unfinished Struggle for Democracy. Cambridge, MA: Harvard, 2004, 184-193.

${ }^{14}$ Schell, Jonathan. The Unconquerable World: Power, Nonviolence, and the Will of the People. New York: Metropolitan, 2003, 91-93. 
The answer to this question is likely to be outside the scope of this discussion, and could in fact merit its own study, but for the purposes here a fitting enough response can be provided. It would appear from the record of the speeches, writings, and tactics of those involved in radical black movements, that although these foreign national liberation movements were important, they were simply a catalyst, not the sole source of these sentiments. I am basing this on the fact that across the board, from Malcolm X to Martin Luther King Jr., the use of foreign thinkers such as Gandhi was only a part of their vision for America. King used Gandhian notions of nonviolent resistance not to define his movement, but rather as a compliment to his uniquely American vision for freedom and equality for all of America's citizens. ${ }^{15}$ Similarly, although they made it a habit of citing Mao and formed public alliances with Ho Chi Minh, the Black Panthers were much more modeled after the thought of Malcolm X than after any third-world national liberation movements. Although Huey P. Newton in particular was committed toward presenting a Marxist critique of the conditions facing poor blacks in America, it isn't clear that he ever fully developed any of these ideas.

Further evidence of this separation can be found in a statement made by Bobby Seale, years after his involvement in the creation of the Black Panther Party, regarding the use of Mao's "Little Red Book." He admits that one of the primary means used by the early BPP to gain the money required to buy shotguns was to buy Chairman Mao's book from small Chinese grocery stores in San Francisco on the cheap, and then drive

\footnotetext{
${ }^{15}$ See: King, Martin Luther Jr. "Letter From a Birmingham Jail." Why We Can't
} Wait. New York: Mentor, 1964, 76-95. 
up to Berkeley and sell them for a high markup, without reading them. ${ }^{16}$ We can see then that although they certainly did rely upon foreign radical thinkers, it was not solely for ideological concerns, but also out of economic concerns.

This is not to say that these national liberation movements had no effect upon the course of radical thought within America, but it is rather meant to illustrate the fact that there was already the level of frustration with the power structure needed to cause many minorities to seek answers outside of the dominant discourse. In this regard the BPP and leaders such as Malcolm X were similar to Louis Hartz' conception of "socialists in the wilderness," by which he meant to argue that the early American socialist movements were much more akin to their liberal American peers than they were to any forms of European socialism. In this regard, the radicalism found in later periods of American history actually can be explained in very similar terms as those used by Hartz to differentiate between European socialists and their American counterparts. The central difference is the fact that although there were certainly some conditions that were similar for many people in the third-world and America, it was, as Hartz put it, like comparing a "postage stamp to a life-size portrait." 17

Having said this, there is a case to be made that although they didn't exist in the same social environment as many third world peoples, African-Americans did live in conditions so far removed from the standard of most American citizens that the Hartz argument is weakened. It is weakened because the comparison between white

\footnotetext{
${ }^{16}$ Interview with Bobby Seale found in: Berkeley in the Sixties. Prod. Mark Kitchell, 117 min. Kitchell Films. 1990. DVD.

${ }^{17}$ Hartz, Louis. The Liberal Tradition in America. San Diego: Harvest, 1991, 244.
} 
socialists and black radicals needs to take into account the unique position that blacks in America occupied due to the presence of Smith's notion of ascriptivism and the impact that this had upon the content and level of frustration found in their political thought.

It is also a different situation because although there were certainly elements of American liberalism within the African-American radical groups, there is also a great deal of frustration and skepticism for ideas that had been so celebrated yet at the same time denied to a good deal of America's minority population. Although their derivation from the ideals of the American Creed were certainly worn proudly, these radical groups' visions for the future were actually liberal in character, but without the sort of implied endorsement of the American experience that was found in such groups as the socialists which Hartz was concerned with.

This is a rather convoluted notion, perhaps because the bedrock ideas found within liberalism are so hard to separate from modern political thought. For example, one could make a quite compelling case that despite the use of his works by those portraying themselves as anti-liberal, the central themes found within the work of Karl Marx are in fact quite complementary to liberal visions of the proper ordering of human societies. Marx's concern was that capitalism was a force that served to sever ties between human beings, and that the end of capitalism would come not from the leadership of a vanguard group of radicals but from the organic desires of the mass of society to remove the chains which capitalistic development had constructed for the 
human mind and body. ${ }^{18}$ In this sense, can we separate the freedom found in liberalism from the freedom sought by Marx? I suppose many Marxists would answer yes, that liberalism is too bound within capitalism and vice versa, that only radical shifts in political thought could end the suffering of the many, but I do not find these arguments compelling enough to abolish any notions of the similarities between the critical ideas of Marx and those of traditional liberalism. ${ }^{19}$

Again, this is not an attempt to argue that groups like the Black Panther Party or the Students for a Democratic Society were really just liberals who put on a fancy show of being radical. Rather, it is meant to illustrate the idea that even when radical beliefs are held firmly and there is a reasoned distaste for the practices of liberal government, there is enough evidence to show that the end goals of these radicals are much more akin to liberal values of individual liberty, democratic governance, and equality of opportunity than the radicals would like to acknowledge.

This moves us to an interesting point, where we can wonder whether the American society against which the Black Panthers were fighting was itself representative of the liberal values of the American Creed. We can already see from the work of Smith that in fact many of the policies enacted by the state and much of the thought of political and economic elites was shaped by a view of minorities that held them as inferior. The fact that so many were excluded, taken with the means

\footnotetext{
18 "Manifesto of the Communist Party." Found in Tucker, Robert C. ed. The MarxEngels Reader. $2^{\text {nd }}$ ed. New York: Norton, 1978, 473-500.

${ }^{19}$ For a thorough discussion of the relationship between Marxism and liberalism see: Kymlicka, Will. Contemporary Political Philosophy: An Introduction. $2^{\text {nd }}$ ed. New York: Oxford, 2002, 166-201.
} 
used to justify this exclusion, provides evidence to support the claim that even the so-called liberals against whom the radicals of the 1960 's were fighting were not upholding the standards of the American Creed. Evidence of this can readily be found in the critique by the young radicals of the "Old Left," the generation of American leaders that had fought for labor rights and a more broad equality but who had altered course in the early days of the Cold War, and in so doing had abandoned anything that could be regarded as "Red." 20

In conclusion, it has been argued here that radical political ideas, although highly dependent upon their historical place, can be defined as those ideas that emerge as a counter to the dominant discourse that shapes much of the social world. Within America, it was argued that radical political ideas have most often been held by those minority groups that found themselves victims of ascriptive Americanism, and that even though foreign ideas of national liberation and revolution were certainly important, it was the American Creed that provided these groups with their underlying perspectives and goals, due to the amorphous nature of the Creed. In the following chapters, the ideas put forth by the Black Power movement's most notable figures will be analyzed in order to provide a backdrop against which to view the emergence of the Black Panther Party, a radical black organization that sought to distance itself from the dominant discourse of their time in its opposition to the Vietnam War, the policing of America's urban centers, and the treatment of poor blacks throughout the country. Throughout the discussion, the Panthers will be regarded as a radical group in terms of

${ }^{20}$ Gitlin, Todd. The Sixties: Years of Hope Days of Rage. New York: Bantam, 1987, 62-65. 
their relation to the broader society, but not so radical that their ideas should be seen as separate from the American Creed. 


\section{Ascriptive Americanism and the Message of Black Power}

Having outlined the past and present conceptions of how American political thought fits in with the ideas of liberalism and democracy, and the problems posed to such conceptions by the historical treatment of blacks, women, native Americans, and other minority groups, it is necessary to examine the emergence of the ideas about "Black Power" and the problems with the power structure that would come to influence the Black Panther Party. In doing so, it will be necessary to push Rogers Smith's conception of ascriptive Americanism further, in order to understand what it was that figures like Malcolm X and Stokely Carmichael were frustrated with, and how this knowledge impacted their positions. Of course, one could devote an entirely separate paper toward the nature of ascriptive Americanism in the mid-twentieth century, so there will be only a brief description of some of the more generally ascriptivist practices, which will be followed by a discussion of the message presented by Malcolm X in his post-Nation of Islam days, as well as the formal arrival of the term Black Power into the American political dialogue. The aim is to present the foundations of radical thought upon which the Black Panther Party would later build and describe how this radical stance was a rather rational reaction to conditions in urban America. 


\section{Ascriptive Americanism and the Urban African-American Population}

In order to understand the frustrations expressed by such figures as Malcolm X, and later by the Black Panther Party, it is necessary to understand the context of urban dwelling African Americans within the broader American political landscape. As has been documented beginning in the 1930's and continuing through the 1950's, a great number of blacks migrated from the south to Northern cities like Chicago, New York, and Oakland. ${ }^{1}$ At the same time, many whites began relocating to suburban areas, a phenomenon later dubbed "white flight." There are many factors explaining this movement, ranging from the lack of jobs and terrible social conditions that faced blacks in the South, to the phenomenon of the baby boom and the creation of many of these suburban areas following World War II. Also, a key factor pushing both the movement of blacks to the north and their increasing calls for social and political equality was that many African-Americans had been employed either by the government or by private firms to build military equipment and fill jobs left by whites who went off to fight in World War II. Aside from these blacks, who performed supporting tasks on the home front, there were also a good number who were stationed overseas and who performed vital tasks, but were forced to work in segregated units. The returning black soldiers and those who had worked to keep the nation's war industry churning would become, like those blacks who returned from World War I,

\footnotetext{
${ }^{1}$ McAdam, Doug. Political Process and the Development of Black Insurgency, 19301970. Chicago: University of Chicago., 1982, 78.
} 
frustrated with a society in which those whose labor had helped to win the war were still regarded as second-class citizens. ${ }^{2}$

Regardless of the reasons given, it is safe to say that the composition of the American city became fundamentally altered in these years, and the influx of AfricanAmericans to these urban centers led to the emergence of a more subtle ascriptivism than that found in the South. As the success of the Civil rights movement was able to show, the majority of American citizens could not accept the type of outright discrimination and oppression that was going on in the Southern states. Even if many white Americans were inclined to distrust or dislike blacks, they were not able to accept the type of treatment that was standard in the Jim Crow South.

This is perhaps why the tone and content of Malcolm X's speeches and writings differs so much from that found in Martin Luther King Jr.'s tactics and message. The glowing and positive fusion of Christian messages of brotherhood, Gandhian notions of non-violence, and American liberalism used by King and his comrades worked so effectively because of the contrast they provided to the harsh and cruel treatment of blacks in the Jim Crow South, perhaps on display best in the landmark "I Have a Dream" speech delivered on the steps of the Lincoln Memorial in 1963;

...I have a dream that one day this nation will rise up and live out the true meaning of its creed: "We hold these truths to be self-evident, that all men are created equal." I have a dream that one day on the red hills of Georgia, the sons of former slaves and the sons of former slave owners will be able to sit

\footnotetext{
${ }^{2}$ Klinker, Philip A. and Rogers M. Smith. The Unsteady March; The Rise and Decline of Racial Equality in America. Chicago: University of Chicago, 2002, 202204.
} 
down together at the table of brotherhood....And when this happens, when we allow freedom ring, when we let it ring from every village and every hamlet, from every state and every city, we will be able to speed up that day when all of God's children, black men and white men, Jews and Gentiles, Protestants and Catholics, will be able to join hands and sing in the words of the old Negro spiritual: Free at last! Free at last! Thank God Almighty, we are free at last! ${ }^{3}$

The message of King and his fellow movement members works especially well with Huntington's and Hartz's conceptions of the power of the American Creed in shaping the political thought of Americans. It was through the use of these sentiments that the majority of Americans were able to recognize the direct conflict between ideals and institutions that was so blatantly obvious. In the northern urban centers there were no Bull Connor figures, who were so patently vicious and this made the task of holding the ideas up to the light rather difficult, as Martin Luther King Jr. would come to find out in his later years during his attempt to organize a movement for economic justice.

Another explanation for the success of the Civil Rights movement that does not hold the American citizenry in such high esteem revolves around the increasing tensions between the US and the Soviet Union in the early days of the Cold War. According to this explanation, Jim Crow laws were not abolished because of some universal call for equality and liberty, but rather because battling for the hearts and minds of the world's non-aligned states required that images from America not be filled with whites beating blacks, sending attack dogs after children, or spraying

3 "I Have a Dream." Found in: Carson, Clayborne and Kris Shepard eds. A Call to Conscience: The Landmark Speeches of Dr. Martin Luther King Jr. New York: Warner, 2001, 85-87. 
defenseless people with high-pressure fire hoses. To back up this view, public opinion polls are available that indicate that in 1964 a majority of the American public felt blacks were pushing too hard for equality, and by 1968 this majority had grown to $85 \%{ }^{4}$ What this shows is that perhaps the idea that the Civil Rights movement was successful because it played to the American Creed is faulty, and that the reasons behind the success were much more of the practical political variety.

This idea is quite persuasive, and is one that cannot be ignored, but it does not necessarily discount the idea that calls to the liberal elements of the American Creed worked in the favor of the Civil Rights movement by persuading the American people that blacks deserved to share in the realization of the Creed. Take the Freedom Riders for example; young people, some black and some white, who risked their lives for the cause of bringing the vote to blacks in the South. ${ }^{5}$ This was clearly an endorsement of the idea that for at least a large number of Americans the blatant unequal treatment of blacks in America was unacceptable and had to be stopped in order to allow the Creed to mean something beyond being a tool used by elites for rallying political support. The fact that they would put their lives on the line emphasizes the power of these ideas.

Also, the "Cold War necessity" argument is interesting because it was the very values that were being denied in the Jim Crow South that the United States took as a credo to contrast Soviet totalitarianism. It would be a fair comparison to take the elite

\footnotetext{
${ }^{4}$ Klinker and Smith, 280.

${ }^{5}$ Gilin, Todd. The Sixties: Years of Hope Days of Rage. New York: Bantam, 1987, 136-139.
} 
rhetoric coming out of post WWII America and contrast it to similar periods, the Jacksonian era for example, to determine how similar the uses of Creedal values were. Perhaps the Cold War represents the type of event that elites seized upon to play the "Creed Card," which in reality was much more of a tool to consolidate power than anything resembling a true effort to bring freedom and justice to the world. Within this context Klinker and Smith's portrayal of leaders such as Truman and Eisenhower being torn between maintaining connections with key senators and elites from the South, and addressing the problem that race in America had become, once exposed through the international press, is telling. It shows that although they were certainly concerned with the injustices of the South, it was out of political necessity that they softened their stances on the issue, making both leaders' calls to Creedal values ring hollow to a certain degree. ${ }^{6}$ Having said this, both Truman and Eisenhower were reportedly moved from their personal racism upon understanding how much AfricanAmericans had already sacrificed, and were willing to sacrifice, in order to serve in the armed forces, despite their unfair treatment both within the military and in the public sphere. ${ }^{7}$

Here is where ascriptive Americanism rears its ugly head, it can be used to understand why there was not the sort of popular movement to improve the conditions of northern, urban African-Americans that typified the movement to end Jim Crow laws in the South. Perhaps to many Americans the blacks in the northern cities that were suffering from the brutality of the police, unfair housing practices, and political

\footnotetext{
${ }^{6}$ Klinker and Smith, 204.

${ }^{7}$ Ibid, 221, 236.
} 
marginalization were regarded in the same way that many immigrants to the United States were in years prior. That is, based upon faulty notions of human evolution poor people were often seen as the losers in the so-called "Lockean race." This term is used by Hartz to describe the usage of liberalism to justify inequalities within the capitalist system. ${ }^{8}$ In this conception, the winners of the Lockean race are those individuals that are willing to put forth labor in order to reap profit, and the losers are those that are unwilling to devote their labor. In this regard they were either unfit to govern themselves in the same way that whites were, or were somehow to blame for their social position. Here Smith's work should be taken into account, as well as the work of John Higham, who conducted a study of the fits and starts of nativism within the United States. ${ }^{9}$ In both thinkers' conceptions of the course of American politics, a certain trend is revealed that shows that at many times throughout American history elites have relied upon the specter of the unwashed masses to rally political support for their ascriptivist policies. These periods could be seen as antithetical to those described by Huntington, because they are defined by fundamental deviations from the liberal ideals embodied in the American Creed, even when these are dressed up so as to appear to be in line with the doctrine of the Creed, as was the case, for example, with the rise of the robber-barons or captains of industry, who used social Darwinist

\footnotetext{
${ }^{8}$ Hartz. The Liberal Tradition in America. San Diego: Harvest, 1991. ${ }^{9}$ Higham, John. Strangers in the Land: Patterns of American Nativism, 1860-1925. New Brunswick: Rutgers, 2004.
} 
arguments to justify their rise to power and their massive wealth, as well as the reason that the poor were not like them. ${ }^{10}$

It should also be noted that in many cases these periods were brought about by shifts in the economic landscape. For example, the 1890 's became a period of great anxiety about foreigners as economic growth slowed and a labor surplus emerged. ${ }^{11}$

During this time, the immigrant became a worry to the capitalists of America, and as a result an effort was made to portray immigrants as threatening, both in the sense that they were likely to be criminal and also in the sense that they were taking jobs away from hard working whites. This lead to increased fear among the working classes that newly arrived immigrants were not only inferior and dangerous, but threatened to steal jobs from full-blooded Americans if they were allowed to come to the US.

Just as social Darwinist arguments placed southern and eastern European immigrants, specifically Italians, Russians, Poles, and Jews within the lower rungs of the human scale of excellence, these ideas also regarded blacks as inferior to whites, often citing studies of the cranium sizes and capacities of blacks, as well as more general statements regarding their tendency toward illegal behavior. ${ }^{12}$ Smith is keen to observe that even among some of the champions of Progressivism of the early

\footnotetext{
${ }^{10}$ Turner. Fredrick Jackson. The Frontier in American History. New York: Dover, 1996, 58-61.

${ }^{11}$ Higham, 68-76.

${ }^{12}$ Smith, Rogers. Civic Ideals. New Haven: Yale, 1997, 364. Also see: Higham, 158.
} 
twentieth century these pseudoscientific ideas regarding racial hierarchy were widespread, even endorsed by Theodore Roosevelt. ${ }^{13}$

One of the most salient issues in the context of this discussion revolves around the problem of the high incarceration rates of black men, and the related failings within the justice system that should be seen as the key factor behind such high rates. As Malcolm X and perhaps more directly Eldridge Cleaver point out, both at the time of their writings and experiences, as well as today, there is a certain tendency on the part of juries, judges, prosecutors, and the broader society at large to equate AfricanAmerican men with criminal activity. ${ }^{14}$ Whether it was earlier fears of the black man's alleged sexual appetite for innocent unwitting white women or the more recent fears of a generation of super predators, there is a very clear pattern within American society of "criminalizing" African-American men, in a fashion similar to that used to portray immigrants such as Italians as dangerous thugs. ${ }^{15}$ Cleaver speaks of this in his popular book entitled Soul on Ice, where he explains how he was sent to jail twice, and also about his subsequent experience in being socialized into prison life. ${ }^{16}$ Malcolm X also reveals a similar experience with the law in his autobiography. ${ }^{17}$

${ }^{13}$ Campbell, Angus and Howard Schuman. "Racial Attitudes in Fifteen American Cities." Supplemental Studies for the Advisory Commission on Civil Disorders. Institute for Social Research: University of Michigan, 1968.

${ }^{14}$ Cleaver, Eldridge. Soul on Ice. New York: Ramparts, 1970.

${ }^{15}$ Oliver, Mary Beth. "African American Men as "Criminal and Dangerous": Implications of Media Portrayal of Crime on the "Criminalization" of African American Men." Journal of African American Studies. 7(2), 2003, 3-18.

${ }^{16}$ Cleaver, 30-36.

${ }^{17}$ Haley, Alex. The Autobiography of Malcolm X. New York: Ballantine, 1992. 
What is apparent from these two works is that there is a great degree of inequality with regards to the treatment of blacks within the justice system. In many cases, African Americans are convicted of crimes by white juries, which is not to impinge the credibility of all whites who have served jury duty. Rather this shows that black defendants are facing an uphill battle from the start in many cases; they must rely upon the judgment of individuals who have often not shared kind of life experiences, and who have possibly come into the courtroom with preconceived notions about black criminal behavior.

In an earlier section, Michel Foucault's work on dominant discourse was used to illustrate the position of the Black Panther Party and other minority groups within the broader context of American political thought. Foucault should be referenced again here because he did a great deal of study into the phenomenon of incarceration in the Western world. His concern was that prisons and prisoners had become a necessary element to life in the modern Western world. ${ }^{18}$ The creation of a prison system required that there be a segment of society, criminals, who could be seen as those who were broken, and who did not fit into society to such an extent that they had to be separated and monitored. He also discusses the idea that prisoners themselves become socialized to their plight, a sentiment that is echoed in the writings of Eldridge Cleaver and is also reinforced by Malcolm X's early life story.

${ }^{18}$ Foucault, Michel. Colin Gordon ed. Power/Knowledge: Selected Interviews and Other Writings 1972-1977. New York: Pantheon, 1980, 42. 


\section{The Message of Malcolm X}

This tendency to view African-Americans as both dangerous and somehow unfit for success in American society is the foundation of what I have referred to as the more subtle and yet more debilitating discrimination facing those African-Americans who were residing in urban northern cities. It was against this backdrop that Malcolm X emerged as a polarizing and popular figure, who shifted from a hateful interpretation of Islam to a more well-grounded and emotional call for the self-determination of blacks throughout America. It is important to note that the period following his break from the Nation of Islam and his trip to Mecca is the subject of present concern, for although there was certainly the same sense of defiance and anger found throughout his speeches and writings, it was only in his later years that he formulated a message that was not tinged with what can only be called a certain cultist flavor. ${ }^{19}$ Although many aspects of the Nation of Islam's core principles were positive and useful, there appears to be a certain cult of personality built around "The Honorable" Elijah Muhammad that is unsettling. For this reason, the Malcolm X which will be discussed here is the man that broke with the Nation of Islam after realizing that both Elijah Muhammad and his interpretation of Islam were fraudulent.

Malcolm's main message was that the power structure (Congress, the courts, the media,) would not ever take the necessary actions to improve the lives of blacks living within America. ${ }^{20}$ In Malcolm's view then, it was up to the black community to lift themselves up to the point at which actions could be taken toward furthering the

\footnotetext{
${ }^{19}$ Haley, 416-418.

${ }^{20}$ Brietman, George ed. Malcolm X Speaks. New York: Grove, 1965.
} 
progress of racial equality, and in this regard he was at the forefront of the movement to create broad coalitions of black groups, ranging from radicals to more conservative Christian organizations.

What Malcolm X was striving towards was not a political goal in a sense. Rather it was the first step toward bringing urban black Americans to the level at which political goals could be formulated and enacted upon. He was not calling for the state to enact more fair laws and practices in regard to the treatment of blacks in the justice system or in housing procedures but was rather concerned with building up the community to the point at which such measures would emerge organically, so that at some point they would be demanded by a unified body of African-American organizations with enough power to influence governmental actors to such a degree that failure to do so would not be an option. Later he would push this idea further, to the point that he sought to involve the $\mathrm{UN}$ in the struggle for racial equality in America.

In this interpretation of Malcolm X's message and actions he was acting with full knowledge of the problems that ascriptive Americanism had created for the African-American community, most specifically those blacks residing in urban areas who were easily ignored by the power structure. His work is extremely important in understanding the later BPP movement because it seems to be the case that the underlying strategy of the Panthers was quite similar, if not directly descended from Malcolm's efforts to bring the black community to consciousness, not only of their 
stake in society, but of the obstacles facing them in the form of ascriptive Americanism.

One of the most telling indications of his outlook can be found in his view on the struggle for Civil Rights that took place from the late 1950's through the mid 1960's that is largely associated with leaders such as Martin Luther King Jr. and groups such as SCLC, SNCC, and CORE, who were using a blend of non-violent resistance, Christianity, and calls to the American Creed. Malcolm X was at the time a very vocal critic of the movement, arguing that it would prove unsuccessful because of those elements within the power structure, namely white Congressmen, who would oppose any actions meant to bring about equality. He argued instead that the issue of racial justice in America should be brought to the UN, so as to remove the power of determining the fate of the black community from the hands of the white power structure. $^{21}$

His message was clear, the very fact that there had to be a Civil Rights "movement" was an indication that African-Americans were living under repression and marginalization. The real problem was that this was taking place within what had largely been considered the "shining city on the hill" of America, where liberalism had swept away the old guard of tyranny and oppression and had ushered in a new age of individual freedom for all. He was, in effect disagreeing with scholars such as Huntington in his ability to see through the liberal rhetoric and point out the blatant failings of the American state in regards to its treatment of minorities, and in so doing

${ }^{21}$ X, Malcolm. "The Ballot or the Bullet." 1964. Found in: Brietman, 34. 
illuminated the type of ideology that is described by ascriptive Americanism. The same critical spirit was on display when he discussed the reason that there was not much support for the Civil Rights movement on the national level, specifically from the Democratic Party, by pointing to the fact that it was seniority that allowed the "Dixiecrats" to wield so much power, and it was the denial of the vote to blacks that had allowed them to hold power in the first place, indicting the premise that American democracy was based on liberal values of freedom and equality. ${ }^{22}$

We can see from the above discussion of the statements made by Malcolm X that not only was he calling for an end to fantasies about the redeeming nature of the American state, but also a certain level of militancy used to offer a counter-point to the non-violent philosophy of King. In fact, it seems that the slogan "The Ballot or the Bullet" is meant not as a call to arms but as a demand for equal political representation. Although this, and other statements, clearly show a tendency toward a degree of militancy, these calls are quite different from Eldridge Cleaver's later call for the outbreak of race war. In fact, what Malcolm X seems to be in favor of is a strong sense of a willingness to defend oneself, something that the BPP would later embrace fully, taking it beyond calls for self-defense and toward a more threatening "revolutionary" posture.

Taking this into account we can see why this more defiant attitude and message was more appealing for blacks who did not face the kind of blatant Jim Crow discrimination that was so obviously antithetical to the values of the American Creed.

${ }^{22}$ Breitman, 37. 
For it was clear that marches in the streets in support of fairness in the justice system or the employment market would do little to change the types of ascriptive Americanist beliefs that allowed these practices to flourish outside of the patently unjust South. Klinker and Smith deem this racism found in the northern states to be of the private and in some cases de facto variety. ${ }^{23}$ By this they are referring to public opinion data taken from the 1950 s and 60 s which clearly indicates that although whites may have disagreed with Jim Crow racism, they were more than a little wary of actually living with a free and equal black population in their own communities. In this sense, the racism of the north was often not displayed outright, but rather was manifested in discrimination in the job and housing markets for example.

One can understand then how the private racism of the North was perhaps more frustrating on a day to day level than that found in the South, not because the conditions in the South were not brutally oppressive, but because the weight of the sort of de facto racism found in the North may have seemed insurmountable for a good many black Americans. That is, even though the movement suffered a great many losses in the South, ranging from deaths and disappearances of leaders and supporters to political let-downs such as the filibuster of many attempts at passing Civil Rights legislation, the fact remained that the non-violent tactics and the sense of fellowship employed by the southern Civil Rights workers must have given them a certain sense of empowerment that was based in the commonly held beliefs of a dedicated community. Without the sort of blatant target for complaint and action, northern

${ }^{23}$ Klinker and Smith, 325-326. 
blacks were faced with a much greater challenge because the enemy was not an obviously backward bunch of "good ole' boys," but was the broader white society at large, which may go a long way toward explaining the much more sharply defiant tone of leaders such as Malcolm X.

Understanding this message of defiance is very important, for it was this strong sense of defiance that would be echoed later by the Black Panther Party. But we should not be surprised that a movement like this sprang up. Of course a people who had been singled out and had been systematically discriminated against would come to be dissatisfied. The interesting part is that for the most part this defiance was quite democratic, even liberal in nature. Even when the message was one of separation or segmentation the goal was still a better stake in the democratic governance of the country. Even when Malcolm X was at his fieriest, his vision was for a system within America that would allow black communities to elect black representatives who would have enough influence to push for positive change. ${ }^{24}$ I will argue that even the BPP, despite its revolutionary rhetoric, was looking for the same thing, they sought to raise awareness throughout the community and educate future generations to the important issues of their time in order to strengthen American liberal democracy rather than topple it.

\section{"Black Power"}

After Malcolm X was assassinated, most likely by elements loyal to Nation of Islam leader Elijah Muhammad, a young compatriot of Martin Luther King who had broken

${ }^{24}$ Fuchs, 191-192. 
with King in 1964 named Stokely Carmichael emerged as the torch-bearer for

Malcolm's defiant stance. Carmichael had been deeply involved in the struggle for

Civil Rights in the South, coming to lead SNCC, the Student Nonviolent Coordinating

Committee through many of the more storied actions of the movement. ${ }^{25}$ Carmichael, however, became disillusioned with the rather slow-moving pace that leaders like King endorsed.

Carmichael's most controversial and influential moment came in a 1966

speech he gave in which he outlined what he called "Black Power."

...Black Power can be clearly defined for those who do not attach the fears of white America to their questions about it. We should begin with the basic fact that black Americans have two problems: they are poor and they are black. All other problems arise from this two-sided reality: lack of education, the socalled apathy of black men. Any program to end racism must address itself to that double reality...We [SNCC] had to work for power, because this country does not function by morality, love, and nonviolence, but by power. Thus we determined to win political power, with the idea of moving on from there into activity that would have economic effects. With power, the masses could make or participate in making the decisions which govern their destinies, and thus create basic change in their day-to-day lives. ${ }^{26}$

We can see that Carmichael's aim was power; political, social, and economic for African-Americans. He also addresses the problem that many would have with it by mentioning the fears that would be attached to statements like his, and we need look no further for such an interpretation than Samuel Huntington. In the Promise of

${ }^{25}$ Carson, Clayborne. In Struggle: SNCC and the Black Awakening of the 1960's. Cambridge: Harvard, 1996.

${ }^{26}$ Carmichael, Stokely. Stokely Speaks: From Black Power to Pan-Africanism.

Chicago: Lawrence Hill Books, 2007, 18-19. 
Disharmony, Huntington raises the issue of Black Power by arguing that the idea of Black Power ran against the American Creed;

...A slogan like "black power" embodies two negative symbols. First power in general is distrusted and any group that proclaims power as its goal is immediately suspect. Second, "black power" implies power for one group at the expense of others. By so defining its goal, the group sharply limits its appeal. Whites feel compelled by the American Creed to support civil rights for blacks; they are under no such compulsion to support black power. ${ }^{27}$

This is an interesting statement for two reasons; first, the idea that Black Power was meant to imply that the power sought should be gained at the expense of others is a false reading of the idea behind Black Power, as detailed by Carmichael, and second, Huntington perhaps let slip some of the ascriptivism that is so overwhelmingly apparent in his later attack on Hispanic immigrants in his denial of the need for blacks to gain a foothold within the power structure of America. ${ }^{28}$

With his call for Black Power, Carmichael was turning his back on the type of moderate, united front that was represented by the Civil Rights movement. It would prove to be the first step in moving toward a separatist ideology, one that did not seek to gain social inclusion for blacks, but rather sought a divorce from white society, only for the reason that he did not think that white liberals were powerful enough, or competent enough, to take on the forces within the power structure that sought to implement white supremacist policies, making any struggle futile. Carmichael's radical separatism will be taken up in the next chapter, when his relationship to the Black Panther Party is discussed more fully, in part because it actually turns out to be

${ }^{27}$ Huntington, Samuel P. American Politics: The Promise of Disharmony. Cambridge: Harvard, 1981, 188.

${ }^{28}$ Huntington, Samuel P. Who are We?. New York; Simon \& Schuster, 2004. 
a much more alarming form of radicalism in terms of its relation to the American Creed, at least on its face.

It is very important to note here that following the victories of the Civil Rights movement in the South, Martin Luther King Jr. took a turn toward the more radical stance that had defined Malcolm X and Carmichael when he began speaking out against the Vietnam War and organizing the ill-fated Poor Peoples Union that sought to bring about alliances between various ethnic and religious groups, ranging from Native Americans to poor whites. ${ }^{29}$ Interestingly, King himself witnessed the more overt form of racism found in northern cities while in Chicago, where he was part of a demonstration that was met by an angry mob of whites who yelled epithets and hurled bricks. Following this encounter, he would declare that of all the scary situations he had been in, it was in Chicago that he became the most fearful for his personal safety. ${ }^{30}$ This is a good illustration of the phenomenon of northern racism, which it has been argued was perhaps a more difficult obstacle to overcome because of its de facto nature. Of course, the actions of the mob in Chicago were not subtle or private at all, but the fact that they occurred so far removed from places like Liberty, Mississippi or Birmingham, Alabama clearly indicated that the racist sentiments were not limited to the South, that they dwelled to a certain extent throughout white America.

\footnotetext{
${ }^{29}$ Branch, Taylor. At Canaan's Edge; America in the King Years 1965-8. New York: Simon \& Schuster, 2006, 715.

${ }^{30}$ Klinker and Smith, 280.
} 
Following the assassination of King in 1968, riots broke out in more than 125 major cities, resulting in not only an increased level of militancy from many police departments, but also in an increase in the wariness of whites to view the movement toward racial equality as a positive step, in line with the ideals of the Creed. In a report issued by a Presidential Commission that flew mostly under the radar in terms of media coverage ${ }^{31}$ it was declared that the conditions in urban America were reaching such alarmingly drastic levels that there had emerged within the country two societies. ${ }^{32}$ It was also during this time that the pressure upon the Johnson administration to end the war in Vietnam began to escalate. As a result of the increased intensity of criticism over the war there was a decline in the overall movement toward racial equality. ${ }^{33}$ Many of the President's hard-fought programs and pieces of legislation which aimed to address the concerns of African-Americans lost support or were forgotten. Of course, the resulting shift away from Johnson's Vietnam policy, combined with the loss of much of the Democratic South, resulted in Republican candidate Richard Nixon's election to office. Nixon has been remembered as both the symbol of America's rightward shift, and as a contradictory figure regarding matters of racial equality. ${ }^{34}$

Taking this all into account, we can see that the idea of ascriptive Americanism put forth by Rogers Smith in his multiple traditions thesis did not die out in the 1920's, when Smith's account stops, but rather continues to exist to this day. I have

\footnotetext{
${ }^{31}$ Branch, 705.

${ }^{32}$ Ibid, 706.

${ }^{33}$ Ibid, 711.

${ }^{34}$ Klinker and Smith, 294-296.
} 
argued that although the American Creed was an effective tool used by the leaders of the Civil Rights movement, as Malcolm X was keen to point out the very fact that there needed to be a movement for civil rights in a supposed liberal democracy was an indication that perhaps the Creed could only go so far, that the ascriptivist tendency was too strong and the white supremacist position too firm for real change to occur. As the struggle for black equality moved from the Jim Crow South to the urban northern states, where ascriptivism was a less clearly visible burden upon AfricanAmericans, we can see the boundaries placed upon the movement for black equality by ascriptivism. In this regard, Malcolm X's post-Nation of Islam position should be viewed as the catalyst for later radical thinkers, most notably Stokely Carmichael and the Black Panthers, who represented those blacks who were tired of being harassed by the police, frustrated with the politicians who promised change but were unwilling to risk their political power to bring about such change, and frustrated with the mass of white society that seemed indifferent to the problems of poverty and oppression that faced many urban blacks. Even with all of these problems though, the ideas found in the Black Power movement were an expression of the American Creed. 


\section{The Black Panther Party}

Malcolm X, Stokely Carmichael, and Martin Luther King Jr. have become entwined within the story of America in the 1960's, an era that has become celebrated by many as a period of Creedal passion, to use Huntington's description. ${ }^{1}$ It was during the 1960 's that a generation of young people rejected the homogenous nature of post-war America, and fought back against corporate control of universities, Jim Crow racism, and perhaps most importantly the Vietnam war. Various accounts tell the story differently, but it is safe to say that the 1960 's represented a time during which the American Creed became relevant to political thought for many Americans. Although many of the young people involved in the various protest movements may have been hesitant to admit that they were in fact supporters of the Creed, it seems that for all the use of Marxist rhetoric and the flying of North Vietnamese flags the goals of these movements were quite similar, and can be traced back to their origins in the American Creed.

Saying that they were rallying around the Creed does not mean that they were not frustrated with certain elements of American liberalism, the "Old Left," that had abandoned much of their ideological orientation with the outbreak of the Cold War and the need to present themselves as committed anti-communists. Rather, it is meant

\footnotetext{
${ }^{1}$ Huntington, Samuel P.. American Politics: The Promise of Disharmony. Cambridge: Harvard, 1981, 167-221.
} 
to show that the Creed is flexible to a certain extent; it can be molded to fit many needs, be they the need to call out an over-reaching government that sought military conquest in Southeast Asia, or the need to call out Southern racists, the Creed is rather amorphous.

\section{The Emergence of the Black Panther Party}

The Black Panther Party emerged in 1966, the brainchild of two young men in Oakland, California, Bobby Seale and Huey P. Newton. Much has been said about the reasoning and circumstances behind the origin of the Party, and the details of the formation are not important for the task at hand. What is important is understanding that the Black Panther Party emerged in the climate of the late 1960's, a period discussed previously as quite tumultuous, during which time many young people within America had adopted a position against the US war in Vietnam, and had sought to distance themselves from previous generations of "liberals" by seeking to foment a revolution. But revolution here is not meant to describe some type of overthrow of the government; rather the revolution of this generation was based on a fresh interpretation of the American Creed. No matter how hesitant these young people were then (and some remain so to this day) to identify themselves with earlier American traditions, it seems that it was the American Creed that gave so much power to the ideas presented by both the anti-Vietnam movement, and its more important precursor, the Civil Rights movement.

In any event, the emergence of the Black Panthers cannot be understood without understanding the political climate of the time, that of a period of Creedal 
passion. The difference of course, was that the Panther's first members were not the sort of middle/upper class college students typified by groups like the Students for a Democratic Society. Rather, it has been noted that the core group of original members were young men from the streets of Oakland, many of whom had a criminal history of some sort, and who had a very distrustful view of the police department, the judicial system, and the broader political landscape. ${ }^{2}$ It was amongst this audience that Newton and Seale began their mission to bring change to the inner-city AfricanAmerican communities of the US.

Also, Oakland had been a hotbed of activist politics, mostly union related. One such event was a movement amongst railway porters known as the Brotherhood of Sleeping Car Porters, an organization that Hugh Pearson views as crucial to the formation of the Black Panther Party. ${ }^{3}$ Taken with the close proximity of Oakland to the radical mecca that was Berkeley in the 1960's, we can see the unique political and social climate that existed during the time of the founding of the Black Panther Party.

Huey P. Newton, who is seen by many as the catalyst for the formation of the party and its most visible leader had a history in the Black Power movement. He was from Louisiana, and met his compatriot Bobby Seale at Merritt community college in Oakland, where an instructor remembered him as being a very bright young man who was interested in issues of black liberation, and where Seale remembers him as being a very outspoken man, who was not afraid to challenge the orthodox thinking on such

\footnotetext{
${ }^{2}$ Pearson, Hugh. The Shadow of the Panther: Huey Newton and the Price of Black Power in America. Reading, MA: Addison-Wesley, 1994, 112.

${ }^{3}$ Ibid, 14-16.
} 
issues as Civil Rights, and who also took his reputation as a tough guy very

seriously. ${ }^{4}$ Others are not so kind to Mr. Newton, pointing to his frequent dealings with street violence and the use of intimidation and murder against those he perceived as enemies. ${ }^{5}$ Regardless of his criminal life or his drug use, Huey P. Newton was the most outspoken of the Panthers, and clearly the one most interested in bringing a theoretical underpinning to the Black Power movement.

Another prominent Panther leader who was mentioned in the preceding chapter was Eldridge Cleaver, who provided the most militant stance of the BPP leadership. Cleaver, in his famous book Soul on Ice, explains that much of his early life had been spent either being hassled by police or in jail. ${ }^{6}$ Cleaver was also very greatly influenced by the life and works of Malcolm X, having followed the man's struggle while in prison and heading a chapter of the Afro-American Unity group in California prior to his becoming a leader of the Black Panther Party. ${ }^{7}$ It was Cleaver who often made the most provocative statements and seemed to take a certain glee from brandishing weapons and being viewed as a dangerous man by many in the establishment. A scholar recently wrote of Cleaver that although there were many faults in his public persona he was an excellent predictor of issues that would prove to

${ }^{4}$ Seale, Bobby. Seize the Time: The Story of the Black Panther Party and Huey P. Newton. New York: Vintage, 1970, 13-18.

${ }^{5}$ Pearson, 249.

${ }^{6}$ Cleaver, Eldridge. Soul on Ice. New York: Ramparts, 1970.

${ }^{7}$ Branch, Taylor. At Canaan's Edge; America in the King Years 1965-8. New York: Simon \& Schuster, 2006. 533, 
be central to the African-American political community, even if his choice of words was often flawed. ${ }^{8}$

\section{The Message of the Black Panther Party}

The messages and strategies put forth by the Party leadership was quite diverse, with a number of leaders focusing upon the conditions within the urban African-American community, and others focusing more upon the black man's role in the war in

Vietnam. The first and most comprehensive statement of the Party's mission was the Ten-Point Platform, put together by Seale and Newton in 1966;

1. We want freedom. We want power to determine the destiny of our Black Community.

2. We want full employment for our people

3. We want an end to the robbery by the white man of our Black Community

4. We want decent housing, fit for shelter of human beings.

5. We want education for our people that exposes the true nature of this decadent American society. We want education that teaches us our true history and our role in the present-day society.

6. We want all black men to be exempt from military service.

7. We want an immediate end to POLICE BRUTALITY and MURDER of black people.

8. We want freedom for all black men held in federal, state, county, and city prisons and jails.

9. We want all black people when brought to trial to be tried in court by a jury of their peer group or people from their black communities, as defined by the Constitution of the United States.

10. We want land, bread, housing, education, clothing, justice and peace. And as our major political objective, a United Nations supervised plebiscite to be held throughout the black colony in which only black colonial subjects will be allowed to participate, for the purpose of determining the will of black people as to their national destiny.

${ }^{8}$ Self, Robert. O. "The Black Panther Party and the Long Civil Rights Era." 49. Found in: Lazerow, Jama and Yohuru Williams eds. In Search of the Black Panther Party: New Perspectives on a Revolutionary Movement. Durham, NC: Duke, 2006. 9 "Black Panther Party Platform and Program." 1966. Found in: Foner, Phillip S. The Black Panthers Speak. New York: Da Capo, 1995, 2-4. 
Following this list was a direct quotation from the Declaration of Independence that emphasized the underlying message of the BPP, that conditions in urban America were similar to those facing the colonists that came to settle the New World. Clearly this platform was based upon the American Creed, and although there are certainly some elements that indicate a more radical interpretation, such as the call for freedom for black men in jail, this fits with the argument presented thus far, that the radical black movement was a product of internal conditions in America.

One of the BPP's primary concerns was the US war in Vietnam, which they viewed as an imperialist undertaking that made victims of Vietnam's population. Bobby Seale was the most critical of the use of African-American G.I.'s in Vietnam, most likely due to the fact that he had served in the armed forces himself. ${ }^{10}$ The message to young black men in the military was that they were killing people who lived in conditions very similar to those facing African-Americans, and that their presence would be better felt at home, on the front lines of the battle against the police departments of America's large urban areas. ${ }^{11}$ We can see from this that there was ample room for alliances between black and white radical groups on these issues, as both wanted an end to the war in Vietnam, and both painted the US as an imperialist oppressor, violating the true wishes of the Vietnamese people.

The other central focus of the Party leadership was upon conditions at home, where opinions ranged from Newton's call for black unity and organization along the

\footnotetext{
${ }^{10}$ Seale, 8-9.

"Cleaver, Eldridge. "The Black Man's Stake in Vietnam." 1969. Found in: Foner, 100-103.
} 
lines of Malcolm X's Afro-American Unity model, to Cleaver's outright warnings of the outbreak of race war. ${ }^{12}$ The thread running through these sentiments was the idea that blacks in America lacked any real political power. Because of this, there was no way to bring the types of changes to the community that would result in a more fertile ground for the type of complete freedom that the Party leadership envisioned for their people. In this regard the BPP should be seen as a direct descendant of the Black Power concept developed by Stokely Carmichael, who would for a brief time become affiliated with the BPP.

On the top of the list of complaints that the BPP had with the white power structure was the manner in which the African-American community was policed, often by white officers. The famous term used throughout the literature and speeches of the day to describe the police was "pigs." It was the pigs who were seen as the frontline of the imperialist and aggressive US state, and the label was meant to portray them as sub-human and vile. ${ }^{13}$ This frustration with the police is another element of the Panther platform that can be linked very clearly to the American Creed, most notably the respect for legitimate authority and the rule of law that is central to the Creed. It appears to be the case that although some of their actions may have blurred the line between legal and illegal, the vast majority of BPP actions were wholly within the law, and it was the police departments in cities like Chicago and Oakland that were in violation of the law.

\footnotetext{
${ }^{12}$ Cleaver, Eldridge. “A Manifesto.” 1970. Found in: Foner, 119.

${ }^{13}$ Foner, 240.
} 
Eventually, the Panthers would come into many conflicts with police departments across the country, sometimes these conflicts turned deadly, as when Fred Hampton was killed in what the Panthers claimed was an unprovoked attack by police officers, which was naturally painted as a case in which force was justified by the police department. The Hampton case is quite troubling, as it appears that the Panthers and their supporters were correct in labeling Hampton's death an assassination. ${ }^{14}$ In any event, it is clear that the primary domestic concern of the Black Panthers was the treatment of the black community by white police officers and their superiors, and their attention on the police only brought more antagonism from police departments across the country.

We can see from the initial statements and strategies the first indications that perhaps the activist or radical tactics used by the BPP were a sort of smoke-screen for a more traditional call to the American Creed. That is, although couched in the terminology of Marxism and national liberation movements, the fact that the US Declaration of Independence and Constitution played such a prominent role in the most comprehensive statement of the Party's goals, and the fact that the goals themselves were a sort of egalitarian liberal construction of freedom for America's black people indicates that perhaps the Black Panther Party's ideas were not so much radical as they were an interpretation of the American Creed, albeit one that was not blind to the problems that ascriptive Americanism had had for the realization of the

\footnotetext{
${ }^{14}$ See Self, Robert O. and also Churchill, Ward and Jim Vander Wall. Agents of Repression: The FBI's Secret Wars Against the Black Panther Party and the American Indian Movement. Cambridge, MA: South End Press, 2002, 64-75.
} 
Creed for all of America's citizens. This position is bolstered by the shift that the BPP made in the early 1970's when they evolved into a much more robust and moderate group, one that had not given up on the goals of black liberation and power, but had realized some key realities that forced a shift in tactics. For example it was during this time that the group began actively participating in the local politics of Oakland, events which culminated in Bobby Seale's unsuccessful bid to become mayor of the city. ${ }^{15}$

This raises an important question though; why weren't the Panthers able to rally the sort of political and emotional support that the earlier Civil Rights movement leaders had amongst the broader American public? Was it because their militant stance and radical statements were just too much, or did the Civil Rights movement represent the boundaries of the types of change Americans were willing to enact? That is, perhaps the BPP would not have been able to enact the type of changes that they, and Malcolm X before them, had sought regardless of their tactics and message because of the powerful force that racism in America represented.

As has been argued thus far, the BPP was a mixture of the sort of empty, reactionary rhetoric embodied in much of their early Marxist "theory," and a genuine representation of the frustrations and fears that were a very prominent part of life in the African-American communities of much of America's urban centers. This interpretation fits quite well with the concept developed earlier, that within America social conditions are unique due to the lack of any clear definitions of nationality aside

\footnotetext{
${ }^{15}$ Fuchs, Lawerence. The American Kaleidoscope: Race, Ethnicity and the Civic Culture. Hanover: Wesleyan, 1990, 188.
} 
from the American Creed, and as a result the radicalism on display by the BPP and the earlier groups that they were influenced by was tinged by the Creed. However, the Creed that influenced the Panthers was not necessarily the same one that Huntington describes, but was rather the Black Power or African-American Creed, the set of ideas that knew full well the obstacles posed to black equality and liberty by the legacy of ascriptive Americanism and was therefore more concerned with building the black community up to the point at which there would be a strong black coalition that would allow and push for change to occur.

Take, for example, the Free Breakfast programs and Liberation Schools, which should be seen as perhaps the most important strategy taken by the BPP, in that these were positive efforts to improve the conditions within the community. The idea behind these programs was to provide poor children with the same type of opportunity to learn as their white, or not impoverished, peers;

The majority of Black, Mexican-American, Orientals and poor Whites know from their American experience that it is impossible to obtain and sustain any education when one has to attend school hungry...All institutions in a society should be designed to serve the masses, not just a "chosen few." In America this program is revolutionary. ${ }^{16}$

It was seen by the Panthers that providing these kids with a solid breakfast would help them in the classroom, but it was also an obvious means of furthering the Party's cause and bringing in new recruits. Should we view this, as Newton would, as a contradiction, or is there a better explanation to be found? I think there is more good to the Free Breakfast program, enough so as to clear up any contradictions, for the fact

16 "Why the Free Breakfast?" 1969. Found in Foner, 169-170. 
was that kids who wouldn't have had the type of strong role-models and required nutrition that their counterparts outside of the cities had, did receive both. Also, although the Panthers viewed the program as revolutionary because it was a step away from the capitalist idea that goods and services should be paid for rather than free, the idea of providing children with a more robust equality of opportunity can certainly be seen as promoting the American Creed as it has been described thus far because these community development measures were meant to improve the lives of the members within the black community and promote a sense of pride and respect that the Panthers saw as fundamental to bringing change to America's inner-cities that would allow for a more robust equality of opportunity across America.

Another issue which is key to any understanding of the Black Panther Party revolves around the exposure that they received in the mass media during their period of popularity. There are numerous points to be made with regard to the treatment of the Panthers by the media, ranging from the idea that the media presented Americans with a biased and sensationalist picture of militant, angry, and rather intimidating black people with no background information as to why they were engaged in these activities, to the idea that although this was certainly true it was exactly what the BPP wanted the media to portray. ${ }^{17}$ Obviously, there were many sensationalist accounts of the BPP's mission and activities, but it is the second point that is most important for the discussion so far. As noted in Hugh Pearson's work on the subject, the BPP

\footnotetext{
${ }^{17}$ Morgan, Edward P. "Media Culture and the Public Memory of the Black Panther Party." Found in: Lazerow and Williams, 324.
} 
presented themselves in a manner that was a godsend to racists. ${ }^{18}$ By putting forth the image to America that they were militant, armed, and aggressive the BPP was playing right into the fears that many Americans already had, and still do have, of inner city African Americans in general. This is not to condone these types of stereotypical fears, but is rather an acknowledgement that this type of thinking, whether we call it ascriptivism or racism, is a fact of life in America.

The sensationalist tactics also drew the ire of the state, to such a degree that the actions taken by the FBI are rightly seen by many as one of the fundamental causes for the breakdown of the Party. It has been noted that the COINTELPRO operations led by J. Edgar Hoover at the FBI represented some of the most egregious violations of the Constitution in modern American history. The tactics used by agents ranged from deliberately pitting leaders of the Party against each other, in one case by sending letters written by non-existent Party members to leaders meant to antagonize and sow dissention, to the placement of undercover agents in key Party chapters. ${ }^{19}$

Hoover has been quoted as viewing the Black Power movement, and the BPP specifically, as the "single greatest threat to the national security of the United States." ${ }^{20}$ One could likely devote an entire study to the ascriptive Americanist Hoover, who had been a central figure in the state's crusade against communists, Marcus Garvey, Martin Luther King Jr., and a host of other leaders and groups deemed "national security threats." It is interesting that Hoover was most concerned

\footnotetext{
${ }^{18}$ Pearson, 338-340.

${ }^{19}$ Bass, Paul and Douglas W. Rae. Murder in the Model City. New York: Basic, 2006, 102-103.

${ }^{20}$ Ibid, 104 .
} 
with destroying the community programs like the Liberation Schools and Free

Breakfast Program, arguing that they were means of propagandizing blacks. ${ }^{21}$ In fact, no other figure represents the ascriptivist mindset as well as Hoover for his time.

Although it is by no means meant to justify, excuse, or otherwise exonerate the tactics employed by Hoover and his fellow ascriptivists, the Black Panthers did, to a certain extent, bring a lot of this on themselves with their open display of firearms and confrontational stance toward police. Newton argued in 1973 that Eldridge Cleaver was directly responsible for much of the increased police attention and action against the Party, saying that “...Eldridge's rhetoric allowed the police to attack us and murder many of our members without a great community protest in most cases."22

The question which must be asked regarding the police and FBI pressure on the Panthers is, how much they would have had to "tone it down," in order to avoid the reaction they received from Hoover, for as his witch-hunts against both Martin Luther King Jr. and Malcolm X indicates he likely would have been just as adamantly opposed to the Panthers had they been less openly militant. The fact remains however, that he may not have received the support that he did had he not been able to highlight the Black Panther's radicalism in order to present the supposed danger that the BPP posed to the state and the (ascriptivist) American way of life.

\section{Leadership Fragmentation}

The BPP was, of course, not the only radical black movement that emerged during the 1960 's. One of the other groups with a significant following was led by Stokely

\footnotetext{
${ }^{21}$ Churchill and Vander Wall, 68.

22 "Interview With Huey P. Newton." Playboy. 1973, 90.
} 
Carmichael, a former leader of SNCC who had become frustrated with what he saw as white interference with the cause of black liberation. ${ }^{23}$ Carmichael's movement became known as being a cultural nationalist group, one which supported the divorce of black Americans from the culture at large, leading to the eventual creation of African nations where all of the world's black people would live together.

Carmichael's position can be seen as a continuation of the work and thought of leaders such as Marcus Garvey, who in the 1920's and 30's sought to lead a wave of AfricanAmerican emigration back to Africa.

Carmichael was for a brief period a member of the BPP, but left after a rift over the role that white and other non-black radical groups would play in the plans for the realization of the BPP's platform. One of his most vocal critics at the time was Eldridge Cleaver, who was concerned that Carmichael's new path was likely to play right into the hands of those black groups that were not of the leftist persuasion, and to such figures as Richard Nixon. Cleaver pointed to the adoption by the Nixon administration of Cleaver's notion of "Black Power," which Cleaver argued had been transformed into a means of promoting capitalism within the black community and had been seized upon by black leaders that were little more than shills for the white power structure. $^{24}$

This brings up an interesting fact about the Black Power movement and its relation to the state, in that Nixon, for whatever reason actually supported the basic

${ }^{23}$ See: Carmichael, Stokely (Kwame Ture). Ready for Revolution. New York: Scribner, 2003. And Carson, Clayborne. In Struggle: SNCC and the Black Awakening of the 1960's. Cambridge: Harvard, 1996.

${ }^{24}$ Cleaver, Eldridge. "An Interview From Exile." 1969. Found in: Foner, 108-117. 
premise of the movement. That is, while he has been quoted as holding blacks inferior to whites, he was still interested in the idea of minority owned businesses being a means of addressing the problems of inner-city America. ${ }^{25}$ Rather than throwing federal money at the problem by creating large federal programs, as Lyndon Johnson had before, the Nixon administration sought to increase the interaction between minority business owners and the federal government. ${ }^{26}$

The split between Carmichael and the majority of the BPP leadership is quite important for the discussion at hand because it raises some interesting points about the role of radical politics within the broader political landscape, and also can be tied in with the concept of dominant discourse that was discussed in an earlier chapter. That is, from the perspective adopted here, the radicalism seen in such groups as the BPP is a direct result of their marginalization within the broader society. It would seem then, that seeing as how blacks were not the only marginalized group, the most effective means of bringing about positive change would be to form a coalition of minority groups. For, if minority groups were to follow Carmichael's cultural nationalist model and detach themselves from interaction with other, different organizations, it seems as though their total power would be diminished. This is perhaps why the Panthers were committed to alliances with various other radical organizations such as SDS and the Young Lords, a similar group composed of Hispanic-Americans, who the Panthers

\footnotetext{
${ }^{25}$ Klinker and Smith, 293.

${ }^{26}$ Kotlowski, Dean. "Black Power-Nixon Style." The Business History Review. Autumn 1998, 409-445.
} 
saw as comrades in "fighting against the forces of imperialism, capitalism, racism, and fascism."27

There is of course, a downside to this type of broad coalition. Aside from the fact that this kind of rallying together would most likely lead to some organizations being marginalized in the context of a broad minority coalition, this type of union was almost certainly going to be viewed with great alarm by those elements within the power structure that were fearful of radical organizations composed of oppressed minorities. For ascriptive Americanists like J. Edgar Hoover the only threat greater than an angry minority organization would be a coalition of these groups.

Having said this, Carmichael's views should not be discounted; there is certainly a good argument to be made for his aversion to outside groups coming to control the agenda of minority organizations. Also, his ideological position regarding the place of blacks in America is perhaps more fundamentally radical than that put forward by the Black Panthers in that he was representative of a secessionist movement, one that did not seek to bring about the necessary social conditions within America that would lead to greater political power for African-Americans. Instead, Carmichael and his fellow pan-Africanists or cultural nationalists were interested in leading a wave of blacks back to Africa, to build up the fledgling independent nations that were beginning to emerge as colonialism receded. The reason being that he was skeptical that whites in America would ever cede the type of power to blacks that he felt was necessary for a people to participate fully in the democratic governance of

27 "The Black Panther Party Stands for Revolutionary Solidarity." 1970. Found in Foner, 220. 
their society. ${ }^{28}$ However, as an interesting aside Carmichael would eventually become fully committed toward bringing democratic governance to the African nation of Ghana, perhaps indicating that even the leader of a secessionist movement was committed to the core values of the American Creed, even if he didn't think they could be realized in America itself. ${ }^{29}$

One thing that becomes abundantly clear when analyzing the statements and ideological positions taken by the Black Panther Party is that there was a great variance throughout the ranks of the Party leadership, and as the group matured these splits only widened, in part due to the pressure applied by Hoover's COINTELPRO. Of the significant splits between leaders, perhaps none is as important as that between Huey P. Newton and Eldridge Cleaver concerning the role that violence would play in the realization of the BPP's vision for the improvement of black lives in America. On the one hand, Cleaver was well known for his description of the coming race war, which at one point Bobby Seale suggested would be carried out in a guerrilla fashion, with black revolutionaries taking to the rugged mountains of the American West in order to counter the force of the state, in a fashion similar to Mao's revolutionary movement that utilized the Chinese countryside as a base for support. ${ }^{30}$ Taken in the context of the time, I would venture to argue that this type of rhetoric espoused by Cleaver and Seale was used for shock value, and not a valid expression of their vision for the movement. I say that because the idea that a few thousand armed men would

\footnotetext{
${ }^{28}$ Carmichael, Stokely. Stokely Speaks: From Black Power to Pan-Africanism. Chicago: Lawrence Hill Books, 2007, 183-220.

${ }^{29}$ Pearson, 337-338.

${ }^{30}$ Foner, 119.
} 
be able to sustain any type of military engagement with the American armed forces

is almost laughable, and furthermore, the idea that a race war would lead to any sort of positive change for blacks or the broader minority community is not based in reality.

Taking Cleaver's message to be meant as a call for armed revolution falls flat on its face, but perhaps these calls should be seen more for their shock value than for their applicability. In this sense, these sorts of messages most likely did a lot more harm to the movement than any good that came about. Having already drawn the ire of Hoover and the FBI, calls for armed revolution only helped to increase the determination of these actors to squash the BPP. In this regard, the calls to revolution could be seen in the same light as the earlier actions of the BPP, such as their demonstration at the California state capital during which members of the party openly walked the streets carrying shotguns and other weapons. ${ }^{31}$ As Newton would later admit these types of shocking demonstrations most likely did more harm to the ability of the BPP to gain support than any good that came about as a result, and certainly these actions brought about more heat from both the state and federal law enforcement officials who were already wary of the situation;

When Eldridge joined the Party it was after the police confrontation, which left him fixated with the "either-or" attitude. This was that either the community picked up the gun with the Party or else they were cowards and there was no place for them. He did not realize that if the people did not relate to the Party, then there was no way that the Black Panther Party could make any revolution, because the record shows that the people are the makers of the revolution and of world history... We had no influence in raising the consciousness of the

${ }^{31}$ Pearson, 130-131. 
Black community and that is the point where we defected [from the black community]. ${ }^{32}$

Aside from the increased level of harassment by the FBI, the threatening statements and actions supported by Cleaver most likely hurt the cause of the BPP in terms of its support throughout the African-American community as Newton was keen to point out. We have already determined that there is a unique African-American political identity, one that is distrustful of the state and frustrated with living conditions in the black community, but it is still bound up within the broader liberal framework of American political thought. From this perspective, there is likely to be a good deal of support for movements which seek to empower blacks and promote self defense in the face of gross violations of liberty and equality, but it is another thing entirely to attempt an armed revolution against the white power structure.

We could view this unwillingness from a couple of standpoints. One is that the liberal, more traditionally "American," nature of the African-American political identity simply does not equate political change with violence. In this view, blacks were not supportive of calls for race war because they were committed to bringing about positive change through political participation. Even if there was a deserved sharp distrust in the effectiveness of political action to address problems within the African-American community, there was still a shred of hope that at some point the American political system would come to better fulfill the political and social needs of the urban black community. In this regard, the BPP's reluctance to go "underground"

${ }^{32}$ Newton, Huey P. "On the Defection of Eldridge Cleaver From the Black Panther Party and the Defection of the Black Panther Party From the Black Community." 1971. Found in: Hilliard, 200-208. 
should be regarded as an example of this line of thought because they didn't see how it would help their movement improve the lives of blacks in America, due largely in part to the fact that revolutionaries cannot gain the support of the people if they seek to remain hidden and anonymous ${ }^{33}$

Another view is that although they were frustrated with the American political system's inability to address problems within the black community, and therefore sought more radical solutions to these problems, a good number of African-American radicals saw that violent resistance to the power of the state would likely end in their demise. Newton embodies this state of mind for example in that although in his earlier statements he portrayed himself as a sort of martyr, he would eventually turn to a more subtle position that was less committed to a revolution in the streets than it was to a revolution in the minds of black Americans. ${ }^{34}$ Along this line of reasoning, the means to improving the lives of blacks in America would not come from the state, but would come only from the coming to consciousness of the black population as a whole. This is what the Free Breakfast program and the BPP's other community endeavors embodied, an attempt to bring forth positive change by lifting the community up out of the darkness and into the light. ${ }^{35}$ There is still of course an extreme amount of discontent with the white power structure, but there are no delusions about the ability to violently overthrow the mechanisms of this behemoth.

\footnotetext{
${ }^{33}$ Newton, Huey P. "The Correct Handling of a Revolution." 1968. Found in: Foner, 42-45.

34 "Interview With Huey P. Newton." Playboy. May 1973, 73-90.

${ }^{35}$ Foner, 169.
} 
Within this context, there is room to ask the question of how far removed this revised strategy of the Black Panther Party was from the broader values of the American Creed. That is, although certainly at the time, and even today, many members of the Party and supporters of the movement are very hesitant (to say the least) to admit that perhaps they were working within the context of liberalism in its American strain, one can certainly make the argument that ideas of individual freedom and equality of opportunity were much more fundamental to the ideology of the BPP and its sister organizations than were Marxist notions of class struggle and the death of capitalism. One need only examine the usage of Marxism within the statements of such leaders as Newton to see that there is very little in the way of original theory or fresh interpretation, certainly not enough to describe the BPP as a Marxist group. Even if their radical stance is to be taken at face value, how were their views different from those embodied in the American Creed? It seems to be the case that from Malcolm X to the Black Panthers the end goal of their struggle would be the realization of freedom within the black community. This freedom was not MarxistLeninist, or Maoist freedom, there were no calls for the dictatorship of the proletariat or the collectivization of the economy. Rather, it was a freedom that would be married to a robust sense of political participation that can only be seen as liberal and American in character in its endorsement of individual liberty, equality of opportunity, and a respect for legitimate legal institutions.

Another point that needs to be made here revolves around the idea that the BPP was a sister organization to national liberation movements that were sweeping the 
former colonial holdings of the European powers, as well as the notion that the BPP would seek to model itself after communist regimes such as Mao's China or Castro's Cuba, where the power was supposedly with the "people," and the enemies were the "imperialist" Americans and their allies. This position was, of course, not unique to the BPP, it was a sentiment that was held by many of the radical groups toward the end of the 1960 's, and was often represented by the displaying of the North Vietnamese flag at protest events as well as a more general identification with such regimes by the leaders and followers of such groups. ${ }^{36}$

The problem with these displays and positions, is that they were wholly dishonest about the actual conditions within these supposed bastions of leftist hope, that were, in reality, much more repressive and much less tolerant of dissent than America has ever been, and likely ever will be an idea that Newton was forced to address in a televised debate with conservative William Buckley. Buckley pointed out that a Chinese Communist Party official had been quoted as saying that "he did not believe in the right to organize an opposition that is contrary to the dialectics of Marxism." ${ }^{37}$ Newton's response had little to do with the question, in fact he didn't answer it, instead opting to explain his thoughts about how Marx's ideas could be used to understand social movements. ${ }^{38}$ The problem with this answer is that it evaded the

\footnotetext{
${ }^{36}$ Gitlin, Todd. The Sixties: Years of Hope, Days of Rage. New York: Bantam, 1987, 379.

37 "A Spokesman for the People." Found in: Hilliard, David and Donald Weise eds. The Huey P. Newton Reader. New York: Seven Stories, 2002, 267-284. ${ }^{38}$ Ibid, 274.
} 
question posed by Buckley with regards to the squashing of dissent in countries such as China and Cuba.

One response to this important question is that perhaps the fall of the Soviet Union, the increased awareness of the actions taken by Mao and the increased openness of the Chinese state, taken with the work that has been done by historians and journalists to give us a more clear picture of the conditions within these states has allowed us to take a much more enlightened position now than was possible forty years ago. ${ }^{39}$ For instance, the horrors of the Cambodian genocide, perpetrated by a "leftist" regime were only fully understood years after they happened, due to the closed and secretive nature of the Khmer Rouge. ${ }^{40}$ I will concede that perhaps at the time little was known about the true nature of these perceived havens of leftist thought, but will not concede that it was obvious that the type of open and popular dissent embodied by both the Black Panthers and the broader anti-Vietnam movement would never have been allowed in Cuba, China, the Soviet Union, or North Vietnam.

In conclusion, it has been argued that the Black Panther Party emerged against the backdrop of the 1960 's, a period of great social upheaval, presenting an image of armed, politically aware, and frustrated young African-Americans who sought to make changes to the power structure within America. Although this militant attitude likely garnered a good deal of respect and curiosity, it would prove to be among the factors that led to the divorce of the group from the black community. For, as many have

${ }^{39}$ Lewin, Moshe. The Soviet Century. New York: Verso, 2005, 4-6.

${ }^{40}$ Power, Samantha. A Problem From Hell: America and the Age of Genocide. New York: Perennial, 2003, 136-140. 
noted the much publicized presence and message of the Black Panthers and the Black Power movement in general pushed many issues into the mainstream, and did in fact lead to some positive steps toward addressing the problems in urban America, but the loss of prominence meant that many of these victories of the BPP would not be followed by increased measures. ${ }^{41}$

The fact that the stated goals and platform of the group were firmly rooted in a particular interpretation of the American Creed, based largely on the thought of Malcolm X and the Black Power movement that Stokely Carmichael christened, serves to bolster the argument thus far, that American political thought is very much shaped by the American Creed. Again, this usage of the term "American Creed," is meant to describe the basic ideas of individual liberty, respect for legitimate authority, and equality of opportunity that are at the foundation of liberal democracy. Returning to the qualified Hartzian argument, we can see that the Black Panther Party was a uniquely American radical group, that attempted to offer a revolutionary ideology but couldn't escape the boundaries that their presence within American political culture had created for them. And, although the historical treatment of blacks modifies the basic Hartzian concept, it holds firm. Because of this, although the Black Panthers were a radical group in terms of their relation to the broader American society of their time, their political thought was representative of the American Creed and in that regard was not radical at all.

${ }^{41}$ Fuchs, 190-205. 


\section{Conclusion}

The argument presented here is that the radicalism on display in the Black Power movement of the late 1960 's and early 1970 's was not removed from the idea that American political thought is shaped by the American Creed. The Creed was presented as the set of values and ideas that shape the American national identity, and as being defined by its reliance upon the concepts of individual liberty, respect for the rule of law, and equality of opportunity. In order to describe the nature and origins of the Creed it was necessary to present the ideas found within the American exceptionalist school of thought, those thinkers that subscribe to the idea of the Creed's power to shape the political ideas found in America, and the unique historical moment that the birth of America represented. Alongside these ideas, the work of Rogers Smith was presented to illustrate the contrast between the ideas of the Creed and the long history of America's suppression of minority groups. Smith introduced the concept of ascriptive Americanism, a term used to describe the justifications given for the ill-treatment of women, blacks, Native Americans, and Asian immigrants, who had all been regarded as everything but free and equal bearers of natural rights for a large portion of American history.

The notion of ascriptive Americanism was used to provide context to the sources of radical thought within American political thought. First, a definition of 
radical political ideas was provided, that sought to remove some of the vagueness surrounding the idea of radical political ideas. In this regard, radicalism was described as ideas that arise against the dominant discourse within society, often out of the frustration felt by minority groups. In order to place these ideas into context, the sources of the radicalism on display in the Black Power movement was analyzed to determine whether or not it could be thought of as domestic in origin.

Having provided a definition of radical political ideas, it was necessary to briefly discuss the ascriptivist practices occurring outside of the Jim Crow South in order to better understand the message of the Black Power movement. It was argued that Malcolm X in his post-Nation of Islam period best represented the voices of urban African-Americans who had grown all-too familiar with the practices of ascriptivism, and that even his militant stance was not a rejection of the American Creed as much as it was a rejection of the contradictions posed to the Creed by ascriptivism.

After outlining the ideas presented by both Malcolm X, and later, Stokely Carmichael, the focus turned to the Black Panther Party, where it was argued that the Black Panthers represented a rather paradoxical position. On the one hand, their use of the US Declaration of Independence and Constitution to define their goals, and the goals themselves were argued to be brought about by their underlying commitment to the American Creed. On the other hand, their early displays of militancy and bold revolutionary rhetoric alienated them from both the black and white communities, and served to draw an intense level of harassment from the government, most notably from J. Edgar Hoover's FBI led COINTELPRO operations. 
Throughout the discussion the notion of the American Creed was used to illustrate the idea that American political thought is in fact dominated by ideas of individual liberty, respect for the rule of law, and equality of opportunity. This is not meant to argue that any derivations from these values were accidental or isolated, for as the discussion of ascriptive Americanism illustrates, the practices of exclusion and repression found throughout American history have been too entrenched to be viewed as blips on the radar. What can be concluded from the discussion is that the American Creed is an amorphous set of values that can be used to argue both for expansion of liberty as well as for limitations of the scope of liberty. This explains how ascriptive Americanism has flourished alongside the Creed, because the ascriptivists used the Creed to support their positions. In fact it is the presence of ascriptive Americanism that created the radicalism on display in the Black Power movement. The fact that even when these militant voices emerged throughout the African-American population the vision for the future was one rooted in the ideas of liberty and equality helps provide support to the idea that radicalism in American political thought does not exist outside the boundaries set by the power of the American Creed. In this regard, the liberal nature of American political thought can still be supported by the ideas found within American exceptionalism, but the idea that America has always been a liberal culture cannot. For, a liberal culture cannot be one in which significant segments of the population are denied equal opportunity and protection of the law. This however, does not reject the idea that the American Creed is powerful, for as was argued here it 
is the political argument in America, and thusly is the determinant of American political thought, but not American political reality. 


\section{Bibliography}

Bailyn, Bernard. The Ideological Origins of the American Revolution. Cambridge: Harvard, 1992.

Bass, Paul and Douglas W. Rae. Murder in the Model City. New York: Basic, 2006

Berkeley in the Sixties. Prod. Mark Kitchell, 117 min. Kitchell Films. 1990. DVD.

Branch, Taylor. At Canaan's Edge; America in the King Years 1965-8. New York: Simon \& Schuster, 2006.

Brietman, George ed. Malcolm X Speaks. New York: Grove, 1965.

Cambridge: Harvard, 1996.

Carmichael, Stokely (Kwame Ture). Ready for Revolution. New York: Scribner, 2003.

Carmichael, Stokely. Stokely Speaks: From Black Power to Pan-Africanism.

Chicago: Lawrence Hill Books, 200.

Carson, Clayborne and Kris Shepard eds. A Call to Conscience: The Landmark Speeches of Dr. Martin Luther King Jr. New York: Warner, 200.

Carson, Clayborne. In Struggle: SNCC and the Black Awakening of the 1960's.

Churchill, Ward and Jim Vander Wall. Agents of Repression: The FBI's Secret Wars Against the Black Panther Party and the American Indian Movement. Cambridge, MA: South End Press, 2002.

Cleaver, Eldridge. Soul on Ice. New York: Ramparts, 1970.

Foner, Phillip S. The Black Panthers Speak. New York: Da Capo, 1995.

Foucault, Michel. Colin Gordon ed. Power/Knowledge: Selected Interviews and Other Writings 1972-1977. New York: Pantheon, 1980.

Fuchs, Lawerence. The American Kaleidoscope: Race, Ethnicity and the Civic Culture. Hanover: Wesleyan, 1990.

Gaddis, John Lewis. The Cold War: A New History. New York: Penguin, 2005. 
Gitlin, Todd. The Sixties: Years of Hope Days of Rage. New York: Bantam, 1987.

Gramsci, Antonio. Selections from the Prison Notebooks. New York: International. 2005.

Haley, Alex. The Autobiography of Malcolm X. New York: Ballantine, 1992.

Hartz, Louis. The Liberal Tradition in America. San Diego: Harvest, 1991.

Higham, John. Strangers in the Land: Patterns of American Nativism, 1860-1925. New Brunswick: Rutgers, 2004.

Hilliard, David and Donald Weise eds. The Huey P. Newton Reader. New York: Seven Stories, 2002.

Huntington, Samuel P. American Politics: The Promise of Disharmony. Cambridge: Harvard, 1981.

Huntington, Samuel P. Who Are We? New York: Simon \& Schuster, 2004.

King, Martin Luther Jr. Why We Can't Wait. New York: Mentor, 1964

Klinker, Philip A. and Rogers M. Smith. The Unsteady March; The Rise and Decline of Racial Equality in America. Chicago: University of Chicago, 2002.

Kotlowski, Dean. "Black Power-Nixon Style." The Business History Review. Autumn 1998, 409-445.

Kuhn, Thomas S. The Structure of Scientific Revolutions $3^{\text {rd }}$ ed. Chicago: University of Chicago, 1996.

Kymlicka, Will. Contemporary Political Philosophy: An Introduction. $2^{\text {nd }}$ ed. New York: Oxford, 2002.

Lazerow, Jama and Yohuru Williams eds. In Search of the Black Panther Party: New Perspectives on a Revolutionary Movement. Durham, NC: Duke, 2006.

Levy, Bernard-Henri. American Vertigo. New York: Random House, 2006.

Lewin, Moshe. The Soviet Century. New York: Verso, 2005.

McAdam, Doug. Political Process and the Development of Black Insurgency, 19301970. Chicago: University of Chicago., 1982. 
Mills, C. Wright. The Power Elite. New York: Oxford, 2000,Newton. New York: Vintage, 1970.

Myrdal, Gunnar. An American Dilemma: The Negro Problem in a White Nation. New York: McGraw-Hill, 1964.

Pearson, Hugh. The Shadow of the Panther: Huey Newton and the Price of Black Power in America. Reading, MA: Addison-Wesley, 1994.

Power, Samantha. A Problem From Hell: America and the Age of Genocide. New York: Perennial, 2003.

Schell, Jonathan. The Unconquerable World: Power, Nonviolence, and the Will of the People. New York: Metropolitan, 2003.

Seale, Bobby. Seize the Time: The Story of the Black Panther Party and Huey P. Newton. New York: Vintage, 1970.

Singh, Nikhil Pal. Black is a Country: Race and the Unfinished Struggle for Democracy. Cambridge, MA: Harvard, 2004.

Smith. Rogers. Civic Ideals. New Haven; Yale, 1997.

Supplemental Studies for the Advisory Commission on Civil Disorders. Institute for Social Research: University of Michigan, 1968.

Tocqueville, Alexis. Tocqueville, Alexis. Democracy in America. New York: Penguin Classics, 2003.

Tucker, Robert C. ed. The Marx-Engels Reader. $2^{\text {nd }}$ ed. New York: Norton, 1978.

Turner, Fredrick Jackson. The Frontier in American History. New York: Dover, 1996.

Wolfe, Alan. One Nation After All. New York: Penguin, 1998.

Wood, Gordon. S. The Creation of the American Republic: 1776-1787. Chapel Hill, NC: University of North Carolina, 1998. 